\title{
Adolescent Adventures in Geology: Impacts of Geoscience- focused STEM Education Combined with Recreation Activities on Adolescents' Perceived Self-Efficacy
}

\author{
Lauren Janowicz \\ lj0029@mix.wvu.edu
}

Follow this and additional works at: https://researchrepository.wvu.edu/etd

Part of the Outdoor Education Commons

\footnotetext{
Recommended Citation

Janowicz, Lauren, "Adolescent Adventures in Geology: Impacts of Geoscience-focused STEM Education Combined with Recreation Activities on Adolescents' Perceived Self-Efficacy" (2020). Graduate Theses, Dissertations, and Problem Reports. 7819.

https://researchrepository.wvu.edu/etd/7819

This Thesis is protected by copyright and/or related rights. It has been brought to you by the The Research Repository @WVU with permission from the rights-holder(s). You are free to use this Thesis in any way that is permitted by the copyright and related rights legislation that applies to your use. For other uses you must obtain permission from the rights-holder(s) directly, unless additional rights are indicated by a Creative Commons license in the record and/ or on the work itself. This Thesis has been accepted for inclusion in WVU Graduate Theses, Dissertations, and Problem Reports collection by an authorized administrator of The Research Repository @ WVU. For more information, please contact researchrepository@mail.wvu.edu.
} 
Adolescent Adventures in Geology: Impacts of Geoscience-focused STEM Education Combined with Recreation Activities on Adolescents' Perceived Self-Efficacy

\title{
Lauren Janowicz
}

Thesis submitted

to the Davis College of Natural Resources and Design at West Virginia University

in partial fulfillment of the requirements for the degree of

Master of Science in

Recreation, Parks, and Tourism Resources

\author{
Robert C. Burns, Ph.D., Chair \\ David Smaldone, Ph.D. \\ Chad Pierskalla, Ph.D.
}

Department of Recreation, Parks, and Tourism Resources

Morgantown, WV

2020

Keywords: Self-efficacy, outdoor recreation, adventure STEM, adolescents, experiential learning, informal education, formal education, STEM education, summer camp setting Copyright 2020 Lauren Janowicz 


\begin{abstract}
Adolescent Adventures in Geology: Impacts of Geoscience-focused STEM Education Combined with Recreation Activities on Adolescents' Perceived Self-Efficacy
\end{abstract}

\title{
Lauren Janowicz
}

Quality, informal learning techniques combined with outdoor adventure recreation, or adventure STEM programming, is a potentially powerful complement to and extension of formal education (Fu et al., 2015). To address this underexplored field, West Virginia University (WVU) and the United States Geological Survey (USGS) partnered to create a geology STEM, outdoor adventure recreation camp. This thesis research project employed qualitative directed content analysis to examine the potential impacts of this adventure STEM program on participants' perceptions of their outdoor recreation (OR) self-efficacy (Bandura, 1994; Mittelstaedt et al., 2009). Semi-structured interviews were conducted with 15 adolescent participants with an average age of 15 years. The camp program involved adventure activities combined with outdoor and in-class geology-focused informal learning. The curriculum employed was designed using a theoretical framework involving Experiential Education Theory (Kolb, 1984) and SelfEfficacy Theory (Bandura). Participants completed an eight-day adventure STEM program which involved recreation activities such as hiking, rock climbing, whitewater rafting, zip lining, environmental education, biking, fossil hunting, and geocaching. Lessons focused on geologic mapping, basic geologic concepts, historical geology of the Appalachian Mountains, and hydrology and environmental geology. Qualitative, directed content analysis of interviews show results indicating that there was a change in outdoor recreation self-efficacy beliefs due to experiences which took place at the camp program and that campers each had unique experiences related to the main sources and processes of self-efficacy, especially in the context of OR activities and experiences. These described experiences aligned with Bandura's (1977) main sources of self-efficacy and the physiological processes reported fit with his described processes through which self-efficacy beliefs are formed. Notably, the following factors most often impacted all interviewed participants' perceptions and beliefs about their OR-related selfefficacy: confidence levels, the perceived challenge of activities, self-described strong motivation levels to participate in OR activities, coping abilities related to difficult or risky OR activities, previous experiences, and a high interest in OR activities prior to attending the camp. 


\section{Table of Contents}

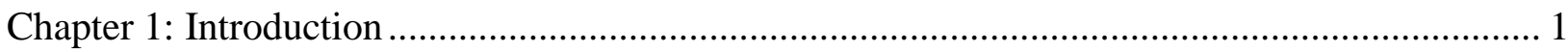

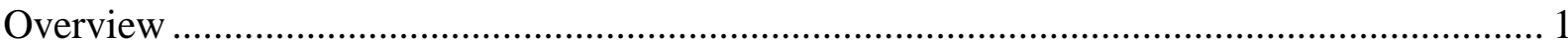

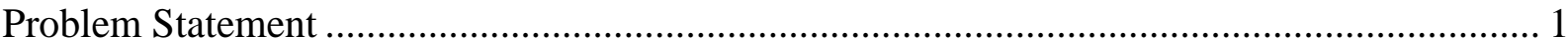

Formal Education System in the United States and How Informal Learning Can Fill the Gaps 2

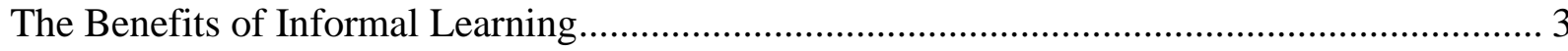

Recreation-focused Informal Learning, Outdoor Education, and Adventure STEM ............... 4

The 2019 Appalachian GeoSTEM Camp............................................................................. 5

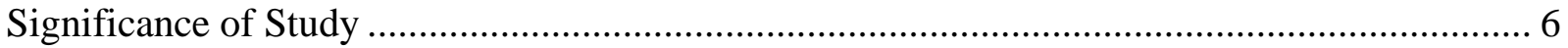



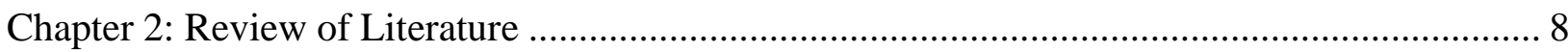

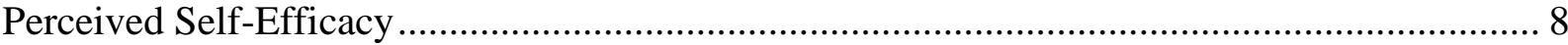

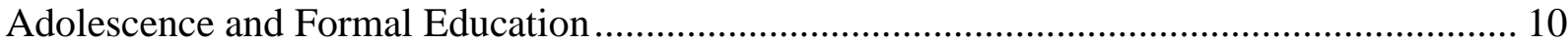

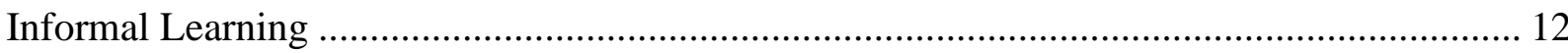

Informal Learning Techniques and Applications ........................................................ 15

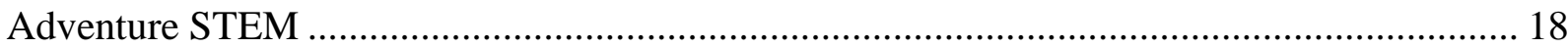

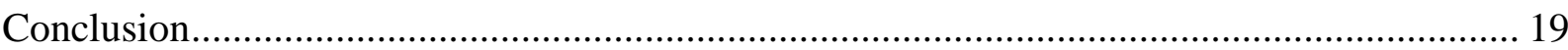

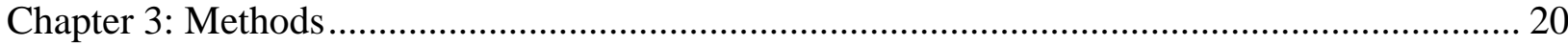

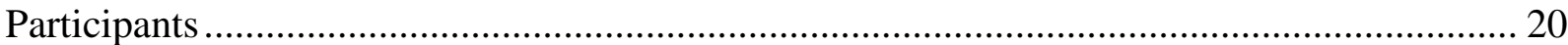

Interview Protocol and Instrument Development .......................................................... 21

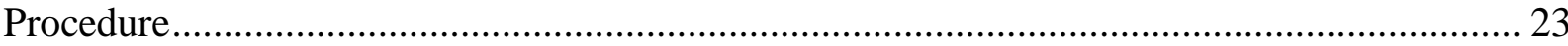

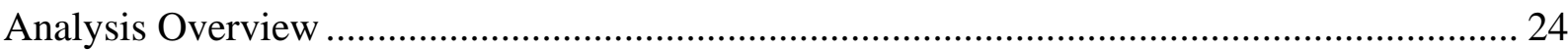

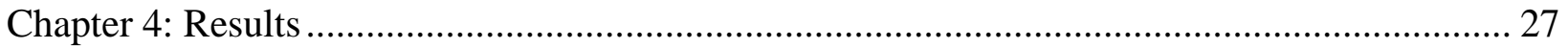

Themes for Research Question 1: How do adolescents' perceptions of their own self-efficacy change after participating in an adventure STEM summer camp? ...................................... 28

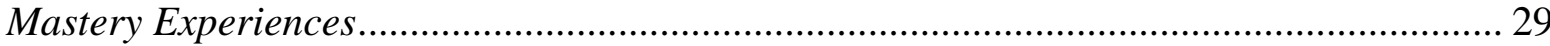

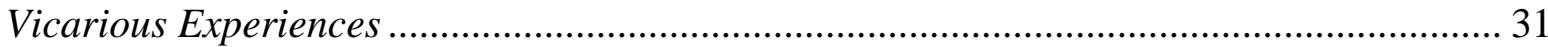

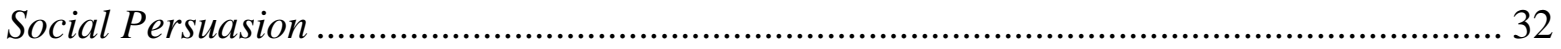

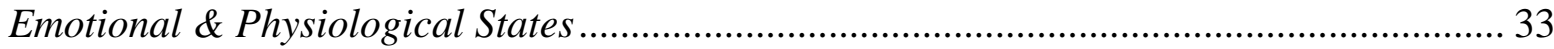


Themes for Research Question 2: How do adolescents experience changes in self-efficacy while participating in an adventure STEM summer camp? ............................................... 35





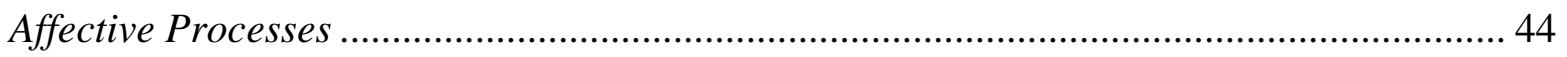

Selection Processes........................................................................................................ 46

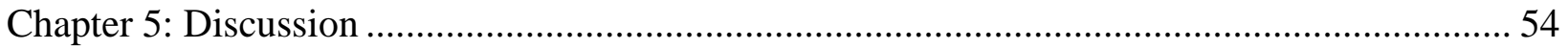

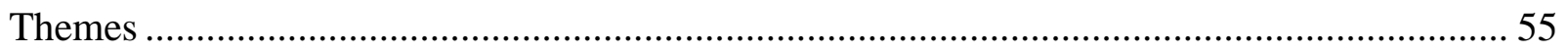

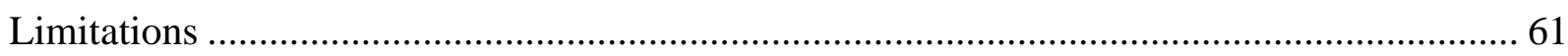

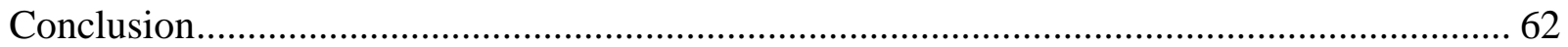



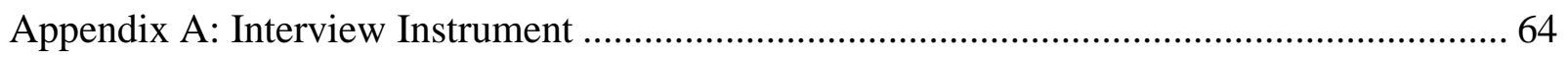





Appendix D: Programmatic Overview of 2019 Appalachian GeoSTEM Camp ................... 69






\section{List of Tables}

$\begin{array}{ll}\text { Table 1: Descriptive Statistics } & 21\end{array}$

Table 2: Connecting Semi-Structured Interview Questions and Bandura’s Major Processes 22

Table 3: 2019 Appalachian GeoSTEM Camp Curriculum Overview 23

Table 4: Theme Overview

Table 5: Coding Table $\quad 66$ 


\section{Acknowledgements}

I am so fortunate to have an incredible, supportive, and inspiring group of people in my life and am so thankful for each and every person who has been a part of this journey.

I express my deepest gratitude to my major adviser, Dr. Robert Burns. You provided me with incredible opportunities to grow academically and professionally, you have encouraged me in my work to be creative and independent, and you have always enthusiastically believed in me. You have continually advocated for me and I would not have had this incredible experience if it weren't for your support. Thank you for your leadership.

Thank you to my adviser, Dr. David Smaldone for all of your hard work, constructive guidance, and encouragement through the many twists and turns of these last few years. I am grateful for your positive attitude and knowledge. Thank you for leading me through the Recreation, Parks, and Tourism Resources program.

Thank you to all of my RPTR professors, Dr. Chad Pierskalla, Dr. Steve Selin and, Dr. Jinyang Deng. I have learned so much from each one of you. Your classes have solidified my passion for this field.

Many incredibly bright and talented people have guided me during this amazing journey. A special thank you to Dr. Ross Andrew and Dr. Mary Allen for mentoring me through this research study and through my time at WVU. Thank you, Dr. Alice Morgan, and Jessica Kaplan for being incredible mentors, confidantes, and friends.

I would like to extend a huge thank you to everyone involved in the Appalachian GeoSTEM Camp, especially Emily Bunse, John Brock, Mitch Blake, and everyone at the United States Geological Survey and West Virginia Geological and Economic Survey. Everyone worked so hard to make the camp incredible and it was a pleasure to work with you all. 
Thank you to the folks at Adventure West Virginia for all of the essential contributions you made to the camp program. A special thank you, C.J. Belknap for your many hours of guidance and your expertise. Thank you to our outstanding camp counselors, Olivia Crum, Conner Hey, and Noah Clune. Your hard work, exceptional skills, and professionalism made the camp an absolute blast and you each were essential in shaping the experience of each camper.

To all of my friends in the Division of Forestry and Natural Resources. It was so inspiring to be with so many people passionate about their fields in natural resources and wildlife. I am so thankful for each of you and cannot wait to see what incredible work you all do in the future.

To all of my friends in beautiful West Virginia, you each made my experience in Appalachia unforgettable and I am forever grateful to have such an incredible group of people in my life.

To my family who have supported me in all of my wild interests over the years and put me in all sorts of informal learning camps. Thank you for your endless encouragement and love. I would not be where I am today if it were not for your advocacy.

To my fiancé, Seth Swary, thank you for your devotion, support, friendship, and love. You inspire and motivate me to learn more about this world and I am incredibly lucky to have you as my greatest advocate. Thank you, I love you. 


\section{Chapter 1: Introduction}

\section{Overview}

This study was designed to gain a greater understanding of adolescents' views of themselves and their abilities related to outdoor recreation (OR) activities after having participated in an adventure STEM camp at West Virginia University (WVU). This thesis research project employed qualitative directed content analysis to explore the potential impacts of the adventure STEM program on participants' perceptions of their own OR self-efficacy with the goal of this research focused on gaining a better understanding of adolescent participants' general perceived self-efficacy and their outdoor recreation-related perceived self-efficacy (Bandura, 1994; Mittelstaedt et al., 2009).

\section{Problem Statement}

The United States is experiencing a shift in understanding the impacts of the formal education system and informal learning through seeing a surge in new research and information related to how different education settings impact young people. At the same time, many institutions within the formal education system in the U.S. are becoming more rigid in curricula. This rigidity is due to the increased focus on high-stakes test scores (Berliner, 2011; Cheryan et al., 2014; Gerber et al., 2001; Rogoff et al., 2016; Sasson, 2014; Toomey Zimmerman \& Bell, 2012). In addition to aiding in moving away from these issues, the informal learning setting may be better equipped to deal with many problems related to youth challenges than formal education can. The increased impacts related to personal growth is one of the areas informal learning can address. To try to further understand the impacts and benefits of informal learning settings on adolescents, this study was focused on a specific adventure STEM camp created by WVU and 
the United States Geological Survey (USGS) called the Appalachian GeoSTEM Camp. This informal learning program linked outdoor adventure recreation and geology-focused STEM topics in a summer camp setting at WVU's Outdoor Education Center and utilized the many resources West Virginia has to offer. This study was focused on adolescent participants' perceived self-efficacy because of its importance in personal growth and academic achievement during a crucial developmental period in a person's life (Curtis, 2015; Perry \& Pauletti, 2011). Moreover, self-efficacy is important because it has many implications for adolescent overall subjective well-being (Artino, 2012; Bandura, 1994; Bandura et al., 2001; Zimmerman \& Cleary, 2006). We sought to understand the possible impacts on adolescent participants' perceived selfefficacy after completing the adventure STEM program by analyzing their self-reported beliefs, perspectives, and reflections expressed in semi-structured interviews at the conclusion of the camp program. Further understanding the impacts of similar informal learning programs may help provide clarity about how adventure STEM should be incorporated in curricula across the U.S. and can provide validity to this type of learning experience.

\section{Formal Education System in the United States and How Informal Learning Can Fill the}

\section{Gaps}

America's youth face a multitude of obstacles and challenges including rapid physical and hormonal changes, and continual psychological and social changes (Curtis, 2015).

Moreover, most young people in the U.S. are enrolled in some form of schooling in the current U.S. formal education system, which is based on the outdated and often detrimental idea of factory model schooling (Sleeter, 2015). Although there are many benefits to formal learning (Marin \& Halpern, 2011; Zimmerman \& Cleary, 2006), there are a multitude of disadvantages to using it alone to educate young people. Among its benefits, formal learning environments push 
adolescents to develop diverse self-regulatory skills and the physical environment can be beneficial to academic achievement (Marin \& Halpern, 2011; Zimmerman \& Cleary, 2006). But even with its benefits, the formal school system is also lacking in certain areas. For example, the physical settings provided by the formal learning environment are occasionally inadequate for students, and these low-quality environments have negative impacts on academic achievement (Cheryan et al., 2014). Additionally, traditional formal education methods can render important topics as boring and difficult to comprehend by students (Sasson, 2014). Lastly, formal learning is taught as solitary (Martin, 2004), whereas informal learning environments foster camaraderie (Denson et al., 2015). With all of these challenges, traditional schools and formal learning environments alone may not be well equipped to deal with adolescent challenges.

\section{The Benefits of Informal Learning}

Many researchers and practitioners have found the term, "informal learning," as difficult to define but often agree that it is characterized by how learning takes place rather than where (Rogoff et al., (2016). Rogoff et al. (2016, p. 358) agree, "It is nondidactic; is imbedded in meaningful activity; builds on the learner's initiative, interest, or choice (rather than resulting from external demands or requirements); and does not involve assessment external to the activity." Informal learning Informal learning alone has many benefits including that it can take place in a variety of settings (Rogoff et al., 2016; Sasson, 2014; Smith-Palmer et al., 2015; Toomey Zimmerman \& Bell, 2012). Informal learning programs are designed to incite personal growth while meeting learning objectives (Locklear, 2013) and unlike high-stakes test scorefocused formal education (Berliner, 2011; Sasson, 2014), these programs put personal growth objectives such as self-efficacy at the forefront of programming goals. Furthermore, informal learning can provide relevance to subjects that are often viewed as boring and difficult to 
comprehend such as STEM topics. Even though STEM is a topic that is difficult to garner interest in, informal learning environments increase students' interest in STEM and the informal environment can make learning fun (Denson et al., 2015; Mohr-Schroeder et al., 2014). Lastly, while formal education can be a solitary experience for the student, informal learning is extremely social and provides opportunities to learn with peers (Denson et al., 2015). With this flexibility in environment, focus on personal growth objectives, social elements, and the relevance this type of education brings to potentially uninteresting topics, informal learning can address the gaps that formal education alone misses.

\section{Recreation-focused Informal Learning, Outdoor Education, and Adventure STEM}

Many current informal learning programs exist today that utilize nature and recreation such as environmental education and outdoor education programs (Denson et al., 2015;

Farmington Hills Nature Center, n.d.; Utah Governor's Office of Economic Development Annual Report, 2020; James \& Williams, 2017; Mackenzie et al., 2018; Michigan Division of Natural Resources, n.d.; Roberts et al., 2018). For adolescents, there are many benefits to outdoor adventure recreation in informal learning including a variety in instructional practices that appeals to a diverse range of students (Denson et al., 2015). Moreover, there are many benefits to outdoor adventure recreation such as identity development, growth in emotional intelligence, opportunities to development autonomy, improvements in mental health, opportunities to overcome physical challenges, enhanced self-esteem, and improved self-efficacy (Duerden et al., 2009; Garst et al., 2001; Jones \& Hinton, 2007; Mutz \& Müller, 2016; Passarelli et al., 2010; Paxton \& McAvoy, 2000; Schwartz \& Belknap, 2017; Shellman \& Ewert, 2010; Widmer et al., 2014). Although research focused on understanding the impacts of informal learning programs that incorporate outdoor adventure is plentiful, little research has sought to understand programs 
that incorporate outdoor adventure recreation and STEM, or adventure STEM. Because adventure STEM combines informal learning, outdoor adventure recreation, and STEM topics, the likelihood that there are benefits to this type of informal learning is high, especially since STEM topics are often considered difficult to understand and irrelevant in the formal learning setting, but are interesting and relevant in the informal learning setting.

\section{The 2019 Appalachian GeoSTEM Camp}

With this lens of informal learning principles, the benefits of outdoor adventure recreation experiences, and the challenges of building relevance with STEM topics, WVU and USGS created the Appalachian GeoSTEM Camp. The intention with the development of this informal learning environment was to give adolescent students experiences through which they can build interest in geology-focused STEM topics, undergo personal growth, gain confidence and self-identity, and establish positive self-efficacy beliefs. The 2019 Appalachian GeoSTEM Camp was an eight-day, informal learning program which combined outdoor adventure recreation activities with geology-focused STEM topics. This summer camp took place in June of 2019 and had 18 participants ages 13 to 17 entering 9th to 12th grade in school the proceeding Fall. This camp is a unique program for many reasons including its utilization of West Virginia University's many resources, lessons from USGS's finest geology and science professionals, emphasis on outdoor adventure recreation, and its novel location in West Virginia, with its plentiful resources in geological and outdoor recreation opportunities. The Appalachian GeoSTEM Camp is the only geology-focused, adventure STEM camp with the incorporation of high-impact outdoor adventure recreation activities such as whitewater rafting, rock-climbing, and zip-lining. Moreover, it is the only geology-focused, adventure STEM program specifically 
for adolescents. The program blended best practices in adventure recreation, informal learning, outdoor education, experiential learning, environmental education, and traditional summer camp.

\section{Significance of Study}

Informal learning in education is an extremely useful way to build the important construct, self-efficacy, and is more beneficial to incorporate in a student's education experience than formal education alone. As the U.S. shifts toward a better understanding of the impacts of formal and informal learning on students, and with the increased pressure on academic achievement coupled with the myriad challenges modern adolescent students face, it is extremely important to continue to determine and understand the impacts of informal learning. This understanding can provide legitimacy to and demonstrate the value of a systemic application of informal learning programming with the formal education system, allowing for the benefits of informal learning to fill the gaps that formal education cannot address. The goal of this research was to add to the understanding of impacts of adventure STEM camp programs by analyzing the perspectives and reflections of participants' experiences. Specifically, this study was designed to gain a greater understanding of adolescents' views of themselves and their abilities related to outdoor recreation (OR) activities after having participated in an adventure STEM camp, or their OR self-efficacy. This research will also provide program managers with information and context needed to improve future camp sessions, thus increasing valuable impacts on adolescents in years to come.

\section{Research Questions}

This thesis research investigates adolescents' views of themselves and their abilities related to outdoor recreation (OR) activities after having participated in an adventure STEM camp at West Virginia University (WVU) and explores the potential impacts of the adventure 
STEM program on participants' perceptions of their own OR self-efficacy with the goal of this research focused on gaining a better understanding of adolescent participants' general perceived self-efficacy and their outdoor recreation-related perceived self-efficacy Bandura, 1994;

Mittelstaedt \& Jones, 2009).

1. How do adolescents' perceptions of their own self-efficacy change after participating in an adventure STEM summer camp?

a. How do adolescents' perceptions of their own self-efficacy related to outdoor recreation activities change after participating in an adventure STEM summer camp?

2. How do adolescents experience changes in self-efficacy while participating in an adventure STEM summer camp?

a. How do adolescents experience changes in self-efficacy related to outdoor recreation activities after participating in an adventure STEM summer camp? 


\section{Chapter 2: Review of Literature}

The following chapter outlines applicable literature on how perceived self-efficacy relates to adolescence and formal education, recreation-focused informal learning, and STEM learning. The chapter begins with a brief review of perceived self-efficacy, the theoretical framework regarding the processes and mechanisms by which self-efficacy beliefs are formed, and the importance of self-efficacy. The review then transitions to adolescence and the benefits and drawbacks of formal education. The section which follows describes how, when systemically combined with formal education, informal learning can aid in addressing the drawbacks of formal education. Next is a brief review of the many techniques and applications of informal learning, namely Experiential Education Theory (Kolb, 1984), outdoor education, adventure recreation, and the summer camp setting. Lastly, the concept of adventure STEM is explored and outlined in the literature and is synthesized as a possible solution to increasing self-efficacy in adolescent students.

\section{Perceived Self-Efficacy}

The theory of self-efficacy was first described in 1977 by psychologist, Albert Bandura, and has often been described as task-specific self-confidence (Artino, 2012). Bandura described perceived self-efficacy as a person's belief in their ability to accomplish a certain task or achieve a specific goal. He posited that self-efficacy beliefs have implications for one's subjective wellbeing, motivation, and can impact many parts of a person's life in that one's outcome expectancies have direct impacts on one's ability to perform behaviors. Bandura theorized that beliefs about one's self efficacy can be developed through four main sources of influence: mastery experiences, vicarious experiences provided by social models, social persuasion, and somatic and emotional states. According to Bandura (1977), the most impactful of these main 
sources of influence by which people gain a strong sense of self-efficacy is mastery experience. Mastery experience involves overcoming obstacles through perseverant effort resulting in either a success or a failure and those with a high sense of efficacy have the staying power to endure these obstacles and setbacks that characterize difficult undertakings (Bandura, 1977, 1994). Those with high perceived self-efficacy will see a difficult task as a challenge that can be mastered while those with low perceived self-efficacy will view the same difficult task as a threat that should be avoided (Bandura, 1994). These benefits can be especially important in the education setting for teenagers who are in a pivotal developmental phase of their lives (Zimmerman \& Cleary, 2006). Researchers have found that simply learning knowledge and skills does not mean that students will apply the information to situations. Students also need to have the motivation and will to successfully function. Research has shown that self-efficacy and motivation are closely related and children who have higher self-efficacy are more likely to engage in challenging learning activities (McGeown et al., 2014). Moreover, academic selfefficacy is linked to academic motivation and achievement, and affects students' performance and learning behavior via their task choices, exertion, and perseverance (Artino, 2012; McGeown et al., 2014). Therefore, researchers have increasingly suggested that education professionals foster self-efficacy beliefs in students in addition to knowledge and skill building (Artino, 2012).

Adolescence is a complex transitional process in which one progresses from immaturity and social dependency into adult life with the expectation of reaching one's developmental potential (Curtis, 2015). Moreover, this period of life, other than infancy, involves more biological, social, and psychological changes than any other life stage (Holmbeck, 2002). In addition to all of the rapid and continual transitions adolescents must endure, adolescents are in a 
time when their developmental and health trajectories can be altered dramatically in positive or negative directions (Curtis, 2015; Holmbeck, 2002). It is crucial that more is understood about the nuance of adolescent development and how it is influenced, especially with factors related to motivation and beliefs about personal abilities, specifically in the informal learning setting.

\section{Adolescence and Formal Education}

Learning takes place in multiple contexts in and out of a school setting and all learners need multiple sources of support from a range of organizations to promote both personal and intellectual development (Banks et al., 2007). Most young people in the U.S. are primarily involved in or at least exposed to formal education and a majority go to school for seven hours a day, five days a week for thirty-six weeks of the year (Gerber et al., 2001). The United States Census Bureau (2019) reported roughly 76.8 million young people enrolled in some form of formal schooling in 2018. The United States formal education system is based on the factory model of schooling which is meant to create standardization and prepare young people to be citizens who fulfill economic roles and maintain social order (Sleeter, 2015). After its fermentation in the late 1800s (Kliebard, 2004), this efficient and mental discipline-focused factory model is still used in the United States with valid reasons. Formal learning environments enhance development and transferability of student critical thinking (Marin \& Halpern, 2011). Additionally, formal learning pushes adolescents to develop diverse self-regulatory skills such as goal-setting, self-monitoring, time management, and self-evaluation (Zimmerman \& Cleary, 2006). When adequate, the physical environment provided by formal education settings can also be beneficial to academic achievement (Cheryan et al., 2014). While there are advantages to formal learning environments, there also are a multitude of disadvantages including heavy institutionalization, an intense focus on high-stakes testing, limited opportunities to participate in 
environmental science, inadequate facilities, and a lack of relevance or difficulties in fostering interest in taught topics (Bandura et al., 2001; Berliner, 2011; Cheryan et al., 2014; James \& Williams, 2017; Ngaka et al., 2012; Sasson, 2014; Sleeter, 2015; Toomey Zimmerman \& Bell, 2012).

Formal education for adolescents is heavily institutionalized and rigid. This institutionalization is often beneficial in that it involves standardization of teaching and curriculum, is long-term, and imparts a structured, controlled environment for learning (Ngaka et al., 2012). Additionally, formal education is monitored by national education authorities and is recognized as the initial basis for education (UNESCO Institute for Statistics, n.d.). However, this institutionalization also produces issues with rigidity such as an increased focus on highstakes standardized testing. This heavy focus on testing over the last two decades has led to an escalated narrowing of curriculum, restricting the creative and enjoyable activities engaged in by teachers and students (Berliner, 2011; James \& Williams, 2017). The narrowing of curriculum to focus on standardized testing scores also restricts thinking skills, retards the development of achievement in later grades, and compromises interpretations of construct validity, ensuring that many important skills learned beyond facts and concepts, and which are meant to prepare students for future learning, will not be taught (Berliner, 2011; DeWitt \& Storksdieck, 2008). Additionally, due to this increased emphasis on test scores, there are less opportunities for children to participate in environmental science outdoors and experience nature via school (James \& Williams, 2017). As a whole, formal education in the United States has gone through many phases of reform such as Common Core Standards and No Child Left Behind yet these efforts are all simply variations of factory model schooling (Sleeter, 2015). Facilities and physical setting play an important role in the United States student formal learning experience. 
Unfortunately, over half of formal education schools in the U.S. have inadequate structural facilities with low air quality, poor lighting, and deficient heating systems. Studies have shown that students in these low-quality physical environments have lower academic achievement (Cheryan et al., 2014).

Traditional formal education methods, in science for example, are considered by students to be boring and render the important content unattractive and difficult to comprehend (Sasson, 2014). Children in the formal education setting often view school subjects as having no relevance to career pursuits (Bandura et al., 2001). Researchers in informal and formal education have found that learners do not act with equal competency performing the same mathematical activities in formal versus informal learning settings. Because of this, Toomey Zimmerman and Bell (2012) suggest a need for relevance or "everyday expertise" in the understanding of applying learned information. This relevance is often not a part of the learning process in the formal education setting. Moreover, formal education heavily depends on cognition and language, and does not focus on the combination of emotion and cognition (Rogoff et al., 2016).

\section{Informal Learning}

In describing informal learning, researchers and practitioners tend to agree that it is defined by how learning is organized instead of where it takes place. Schools can be organized informally and non-school settings can still implement the factory model of instruction widely used in formal education (Rogoff et al., 2016). Informal learning opportunities do not have to be a part of an ongoing school curriculum and are characterized by voluntary as opposed to mandatory participation (Smith-Palmer et al., 2015). Informal learning can take place in many settings, including during play, club membership activities, science outreach programs, and 
museums, but complex informal learning takes place especially in youth education camps (Rogoff et al., 2016; Sasson, 2014; Smith-Palmer et al., 2015; Toomey Zimmerman \& Bell, 2012). Educational camp programming which utilizes informal learning techniques and applications could potentially help formal educators with fostering personal growth development such as self-efficacy in students.

There are countless forms of informal learning such as field trips, youth summer camp programs, and camp education programs, all with varying benefits. School systems and individual teachers often bring their students on field trips to improve their students' cognitive and affective learning. These trips are also meant to provide positive social experiences, create opportunities for learning outcomes beyond facts and concepts, and to prepare students for future learning (DeWitt \& Storksdieck, 2008). Youth camp programs such as 4-H develop programming with the aim to incite personal growth, increase knowledge and competencies, improve youth attitudes toward school subjects, and often use nationally recognized standards as guides to meet learning objectives (Locklear, 2013). Countless research studies have been conducted in recent years which outline the theories and best practices employed by camps to foster positive changes in youth (American Camp Association, 2005). Unlike formal education, youth camp education programs such as West Virginia University’s Science Adventure School put personal growth at the forefront of programming goals and include theories such as Experiential Education Theory (Kolb, 1984) in curricula to attain these changes while students learn science topics (Science Adventure School, n.d.). Moreover, difficult-to-comprehend topics such as STEM subjects can be made more interesting in an informal learning experience (Roberts et al., 2018). This increased interest in STEM is an important component in encouraging students to pursue STEM learning because it contributes to students' learning and 
success in retaining STEM content (Bell et al., 2009; Roberts et al., 2018). Teachers and formal school systems already widely use field trips to enhance curricula and to provide a well-rounded experience for students, but there is vast potential to systemically incorporate informal learning into the United States student experience in a variety of ways, especially via outdoor youth education camp programming, where in-depth conceptual understanding of science can take place (James \& Williams, 2017).

Informal education has the potential to be a powerful complement to and extension of formal education ( $\mathrm{Fu}$ et al., 2015). Informal learning methodologies can address the challenges that formal education models create for student development, including those related to interest (Roberts et al., 2018), personal growth and self-efficacy beliefs (Bell et al., 2016; Lane et al., 2013). Involvement in informal learning can teach students about social structures and provides the opportunity for engagement in consequential learning and the development of new identities (Rogoff et al., 2016). Informal learning can also be beneficial to students' learning (Gerber et al., 2001) and provides real-world links to school subject matter by giving the material context. For example, one study showed that access to informal science education can provide opportunities for youth to increase and maintain long-term interest in and identification with science (Fields, 2009) and therefore creates relevance when formal education often cannot. For teachers, active, subject-integrated experiential, in-context learning is the most effective way to reach students (James \& Williams, 2017), which is more often utilized in the informal learning setting. Overall, there is little consensus of the definition of informal learning, its key features, and an understanding of adolescent informal learning experiences (Gerber et al., 2001; Rogoff et al., 2016) and informal learning experiences being characteristically idiosyncratic and unpredictable (Fu et al., 2015) compounds this difficulty in understanding. Although often 
conflicting, there is plenty of research that outlines the benefits of informal learning programming such as there being more available learning settings (Bell et al., 2016) and higher emotional engagement for students resulting in increased motivation for learning (James \& Williams, 2017). Informal learning programs, especially those focused on science and technology topics, create a more robust educational pipeline for underserved youth (Rogoff et al., 2016) and have the potential to support students' learning and engagement in a formal STEM learning environment (Roberts et al., 2018). Furthermore, experiences in informal STEM learning address the limitations of formal schooling by providing opportunities that build students' awareness of and interest in the STEM fields (Popovic \& Lederman, 2015; Roberts et al., 2018). There are various techniques and applications of informal learning programming, but the present study focuses on the outdoor youth adventure, informal learning, summer camp setting, specifically, adventure STEM.

\section{Informal Learning Techniques and Applications}

In addition to the endless techniques and applications of informal learning programming, there is much flexibility in practice. For example, the informal learning programming for the 2019 Appalachian GeoSTEM Camp utilized Experiential Education Theory (Kolb, 1984), the youth summer camp setting, and outdoor adventure recreation with the goals of fostering STEM interest in participants while providing opportunities for personal growth and intellectual development.

Kolb's Experiential Education Theory is simply learning through experience (Kolb, 1984). Experiential learning is process-focused and involves concrete experiences followed by reflective observation, abstract conceptualization, and active experimentation, and experiential learning demands heavy interaction between the learner and the environment (Kolb, 1984). The 
experiential approach to teaching "is based on the idea that optimal change and growth take place when people are actively (physically, socially, intellectually, emotionally) involved in their learning rather than just being the receivers of information (Stanchfield, 2016)." Learning through hands-on experience allows for more involvement in the subject matter and causes a pairing of concrete memories with gained knowledge, skills, and subject matter (Fägerstam, 2014; James \& Williams, 2017). Research regarding the utilization of experiential learning in educational and vocational programming has shown increases in participant self-efficacy beliefs when experiential learning theory is applied (Banfield \& Wilkerson, 2014; Esters \& Retallick, 2013; Watters et al., 2015). The summer camp setting is an excellent environment for utilizing experiential learning theory and can even be considered the quintessential experiential classroom (Yilmaz et al., 2010). Experiential learning that takes place outdoors "...provides higher level thinking opportunities as well as opportunities to build a range of non-cognitive skills such as cooperation, collaboration, independence, and responsibility (Heinlein, 2017).”

The summer camp setting in the United States provides defining moments in novelty, challenge, friend-making, tradition, achievement, positivity, and safety (Garst et al., 2001). The quintessential summer camp environment has novel educational and social experiences to develop leadership such as ice breakers, outdoor overnight trips, fire building, building counselor relationships, and plenty of outdoor experiences, all while in a safe environment (Martin, 2018). Young people who attend camp develop in the areas of social-emotional learning and skills learned in camp are highly transferable, often leading to successes in school and work. Socialemotional learning outcomes include significant growth in campers' self-esteem, peer relationships, independence, and leadership (American Camp Association, 2005). Moreover, multisensory experiences in the outdoors stimulates students' connections between networks in 
the brain thus producing long-term episodic memories (Fägerstam, 2014). The settings of summer camps are dynamic, and can often include outdoor adventure recreation activities. Camp is a unique educational context and a positive force in youth development, regardless of camp type or session length (American Camp Association, 2005). Wilson et al. (2019) found in a study about transferable learning that summer camp fit into the learning landscape for students by being complementary to school and served as a social respite from school. The summer camp setting is yet another informal learning application that can be a successful, systemic paring with formal education.

Much like in the camp setting, research demonstrates that experiences in outdoor adventure and recreation settings, especially in that of outdoor education programming, facilitate a multitude of positive affective and cognitive outcomes including identity development, increased self-confidence, resilience, intrinsic motivation, relatedness, autonomy, and well-being (Duerden et al., 2009; Houge Mackenzie \& Hodge, 2019). Complementing classroom learning and outdoor adventure education, or outdoor adventure education, can lead to the development skills, beliefs and behaviors that support student achievement in the classroom and beyond. This set of intrapersonal and interpersonal assets (e.g. perseverance, grit, social skills, efficacy beliefs and mind-sets) are desired outcomes which outdoor adventure education is well positioned to deliver (Richmond et al., 2018). Research conducted over the last two decades has demonstrated the value of outdoor education, especially with a focus on experiential learning (Fägerstam, 2014; Finn et al., 2018; James \& Williams, 2017; Mackenzie et al., 2018; Mackenzie \& Eitel, 2017; Mutz \& Müller, 2016; Passarelli et al., 2010; Richmond et al., 2018). Critically, there is currently minimal research in understanding how adventure recreation informal learning 
experiences such as adventure STEM can foster feelings of self-efficacy and how these experiences can be incorporated into the U.S. learning landscape.

\section{Adventure STEM}

Adventure STEM as a concept is sparse in current literature and there is little to no standardization of terms and definitions. Adventure STEM often is either described in other terms such as “Adventure Learning” (University of Idaho, n.d.) or organizations such as the Oak Grove School District claim to have an adventure STEM design but do not actually involve outdoor adventure recreation in programming (AdVENTURE, n.d.) The few programs comparable to the Appalachian GeoSTEM Camp, such as the South Dakota School of Mines Geology Rocks! Summer Camp, involve some outdoor recreation and STEM learning but without a high-caliber adventure recreation component (South Dakota School of Mines Geology Rocks! Summer Camp, n.d.). The sizable gap in the literature demonstrates the need for further investigation and standardization of adventure STEM. Moreover, the benefits of informal learning, experiential education, and outdoor adventure recreation are all present in the adventure STEM experience which further illustrates the need for an understanding of its impacts and possible utilizations. Adventure STEM involves informal STEM learning experiences, such as those described by Roberts et al. (2018). These experiences build students' awareness of and interest in the STEM fields, provide a way to present STEM subject matter in a more engaging, hands-on way, promotes learning through real-world modeling and examples, and help students understand concepts and their ability to recall information (Roberts et al., 2018). The incorporation of informal education programs such as the adventure STEM program in the present study into the United States school system may be an aid in addressing challenges that can go unaddressed in the formal school setting, notably the impacts on perceived self-efficacy. 
Understanding the impacts of programs like the Appalachian GeoSTEM Camp and other adventure STEM programs can help better determine how to approach this possible solution. However, understanding specific outcomes of adventure STEM and similar programming represents an area in need of additional research, especially related to self-efficacy in adolescents. Due to the young and interdisciplinary nature of informal science education and learning, evaluating and understanding outcomes and impacts of these types of programs is challenging (Fu et al., 2015). The present study seeks to address this specific gap by exploring the sources of self-efficacy development in teens by collecting data regarding the impacts of an informal learning adventure recreation, or adventure STEM, program.

\section{Conclusion}

This study investigated the impacts of a geology-focused, outdoor recreation-based adventure STEM program on perceived self-efficacy of adolescent participants. Because selfefficacy has implications for one's overall subjective well-being, specifically factors related to human and academic achievement which adolescents are heavily focused on at their life stage, we sought to investigate the effectiveness of boosting this construct through the employment of informal education via adventure STEM programming. Adding to the understanding of impacts that adventure STEM programming has on adolescents may help lead to a systemic incorporation of informal learning in the U.S. education system. Students spend an estimated $86.7 \%$ of tie outside of a classroom (Denson C., Austin, C., Haley C. et al., 2015). 


\section{Chapter 3: Methods}

This study sought to understand participants' point of view after having experienced the 2019 Appalachian GeoSTEM Camp via directed content analysis of rich data provided by semistructured interviews (Hsieh \& Shannon, 2005). Participants were selected using Nonprobability Convenience Sampling (Ilker Etikan et al., 2016) and interview protocol development involved the use of semi-structured interview questions developed using Bandura's Self-Efficacy Theory (1995), Bandura's guide to constructing self-efficacy scales (2005), and Mittelstaedt and Jones's (2009) Outdoor Recreation Self-Efficacy scale development techniques. Directed content analysis was used in the study because of the role of existing theories having been used to guide the coding process and focus the research questions, and due to the large amount of contextual information available to the researcher (Hsieh \& Shannon, 2005). Analysis was conducted by coding using Dedoose software in accordance with Saldaña's coding methods (2013).

\section{Participants}

Nonprobability sampling was used in this study to choose the sample of participants, specifically, Convenience Sampling was utilized (Ilker Etikan et al., 2016). Convenience Sampling was used because randomization was impossible due to participants of the camp having voluntarily selected to participate in the program (Ilker Etikan et al., 2016). Study participants included $15(83 \%)$ of the 18 adolescents who completed the program with $5(33 \%)$ males and $10(66 \%)$ females. Eighty percent of all participants were West Virginia residents. Those who identified as male had a mean age of 14.8 years-old and those who identified as female had an average age of 15 . The largest student group of the participants were rising tenth graders (33\%). The overall average rising grade was 10.27 with the lowest rising grade as 9 and the highest rising grade as 12 . West Virginia University recruited participants through email 
blasts, flyer dissemination, social media posts and advertisements, school guidance counselor outreach, camp webpages, and word-of-mouth.

Table 1: Descriptive Statistics

\begin{tabular}{|c|c|c|c|c|c|}
\hline & Gender & $N$ & Mean Age & $\begin{array}{l}\text { Mean Rising } \\
\text { Grade }\end{array}$ & $\begin{array}{l}\text { WV } \\
\text { Residency } \\
\text { (percent) }\end{array}$ \\
\hline & $\mathrm{M}$ & 5 & 14.8 & 10.2 & 80 \\
\hline & $\mathrm{F}$ & 10 & 15 & 10.3 & 80 \\
\hline Total & & 15 & 15.05 & 10.27 & 80 \\
\hline
\end{tabular}

\section{Interview Protocol and Instrument Development}

In order to understand whether there was a change in self-efficacy beliefs and how selfefficacy beliefs developed, the study focused on the participants' belief source development. The purpose of this inquiry was to collect meaningful data from the student participants to answer the research questions. Rich, qualitative data were generated from semi-structured interviews conducted near the conclusion of the camp program (Creswell, 2007). Three researchers conducted and recorded interviews using digital recorders with five campers each during evening activities on the last evening of the camp program. Researchers were trained in mock interviews prior to the camp session and were familiar with the construct, self-efficacy. West Virginia University staff and faculty members were selected to interview due to their research experience at the university. After recording, interviews were transcribed in Microsoft Word. Interviews lasted from approximately 7 minutes to approximately 23 minutes in range. Interview questions (see Table 2) were designed to address Bandura's four major processes and four main sources of influence of self-efficacy (1994) and utilized Mittelstaedt and Jones's 
Outdoor Recreation Self-Efficacy scale development techniques (2009). The open-ended prompts asked students to talk about their experiences in the camp program and how they felt about their skills and abilities in different scenarios related to the camp program activities. (Creswell, 2007). Although the interviews were not anonymous, participant information was subsequently removed after data collection to ensure confidentiality. During the transcription process, participants were given pseudonyms to protect their identities. Institutional Review Board (IRB) protocol was approved in December, 2018.

Table 2: Connecting Semi-Structured Interview Questions and Bandura's Major Processes

\begin{tabular}{|c|c|c|c|}
\hline & Question & $\begin{array}{l}\text { Major } \\
\text { Process }(e s)\end{array}$ & Main Source(s) of Influence \\
\hline 1 & $\begin{array}{l}\text { At any point during the camp, did you feel that there } \\
\text { was a time you overcame an obstacle through a lot of } \\
\text { effort? }\end{array}$ & $\begin{array}{l}\text { Cognitive, } \\
\text { Affective, } \\
\text { Motivational }\end{array}$ & Mastery Experiences \\
\hline 2 & $\begin{array}{l}\text { Before this camp, did you think of yourself as } \\
\text { someone who is good at adventuring outdoors? Have } \\
\text { those feelings changed after participating in this } \\
\text { camp? If so, how? }\end{array}$ & $\begin{array}{l}\text { Cognitive, } \\
\text { Selection }\end{array}$ & Enjoyment/Mood, Interest \\
\hline 3 & $\begin{array}{l}\text { What does it mean to you to be good at outdoor } \\
\text { adventure activities? }\end{array}$ & Cognitive & $\begin{array}{l}\text { Enjoyment/Mood, Interest, Mastery } \\
\text { Experiences, Vicarious Experiences }\end{array}$ \\
\hline 4 & $\begin{array}{l}\text { How would you say that other people who know you, } \\
\text { like your friends, teachers, and parents describe your } \\
\text { interest and skill in outdoor adventure activities? }\end{array}$ & $\begin{array}{l}\text { Cognitive, } \\
\text { Selection }\end{array}$ & $\begin{array}{l}\text { Enjoyment/Mood, Interest, } \\
\text { Vicarious Experiences }\end{array}$ \\
\hline 5 & $\begin{array}{l}\text { After participating in the camp, are those feelings } \\
\text { changed? If so, how? }\end{array}$ & $\begin{array}{l}\text { Cognitive, } \\
\text { Affective, } \\
\text { Selection }\end{array}$ & $\begin{array}{l}\text { Enjoyment/Mood, Interest, } \\
\text { Vicarious Experiences }\end{array}$ \\
\hline 6 & $\begin{array}{l}\text { Prior to this camp, how did you feel about doing } \\
\text { outdoor adventure activities such as hiking, biking, } \\
\text { climbing, or rafting? How do you feel about doing } \\
\text { outdoor activities such as these after participating in } \\
\text { the camp? }\end{array}$ & $\begin{array}{l}\text { Cognitive, } \\
\text { Motivational, } \\
\text { Selection }\end{array}$ & $\begin{array}{l}\text { Enjoyment/Mood, Interest, Mastery } \\
\text { Experiences, Vicarious Experiences }\end{array}$ \\
\hline 7 & $\begin{array}{l}\text { Have you ever wanted to quit doing outdoor } \\
\text { adventure activities because of a specific experience? }\end{array}$ & $\begin{array}{l}\text { Cognitive, } \\
\text { Motivational, } \\
\text { Affective }\end{array}$ & Mastery Experiences \\
\hline
\end{tabular}


If so, what happened and how do you feel you handled the situation?

8 Some would say that a lot of the activities you participated in during this camp are dangerous and risky. Do you feel that you can handle pressure well

Cognitive, Enjoyment/Mood, Interest, Mastery Affective, Experiences, Vicarious Experiences when participating in these types of outdoor adventure activities? What do you do to help cope with any pressure?

\section{Procedure}

The 8-day adventure STEM camp, known as the Appalachian GeoSTEM Camp sought to engage participants in informal, geology-focused learning by combining outdoor adventure recreation activities and experiential STEM learning. Using Bandura's (1994) four sources of influence, program strategies sought to increase impacts on adolescents' perceived overall selfefficacy and perceived outdoor recreation-related self-efficacy (Mittelstaedt \& Jones, 2009). Throughout the development of the camp, program managers used an informal education theoretical framework to guide the design. Theories used included Kolb's experiential learning theory (Kolb, 1984) and self-efficacy theory (Bandura, 1994). The camp schedule was developed by matching outdoor adventure recreation activities with compatible geology-focused STEM topics to create an informal learning environment while attempting to utilize available education resources and natural resources (see Table 3).

Table 3: 2019 Appalachian GeoSTEM Camp Curriculum Overview

\begin{tabular}{|c|c|c|c|}
\hline Modules & Description and Goals & $\begin{array}{l}\text { Paired Informal Learning \& } \\
\text { Recreation Activities }\end{array}$ & $\begin{array}{c}\text { STEM } \\
\text { Content }\end{array}$ \\
\hline $\begin{array}{l}\text { Basic Mapping } \\
\text { Techniques }\end{array}$ & $\begin{array}{l}\text { Use apps to navigate outdoors and } \\
\text { collect scientific data. Helps } \\
\text { campers get engaged with the } \\
\text { outdoors without intimidating them } \\
\text { with too much information. }\end{array}$ & $\begin{array}{l}\text { - } \text { Geocaching with GPS \& } \\
\text { paper topographic maps } \\
\text { iNaturalist BioBlitz hike with } \\
\text { zip-lining } \\
\text { - }\end{array}$ & $\begin{array}{l}\text { Science, } \\
\text { Technology, } \\
\text { Engineering }\end{array}$ \\
\hline
\end{tabular}




\begin{tabular}{|c|c|c|c|}
\hline & & from Motion \& Drones & \\
\hline $\begin{array}{l}\text { Basic Geologic } \\
\text { Concepts }\end{array}$ & $\begin{array}{l}\text { Learn relevant geoscience concepts } \\
\text { like the rock cycle, rock and } \\
\text { mineral identification, geologic } \\
\text { time scale, time principles and } \\
\text { relationships, etc. Gives the } \\
\text { campers a geologic background. }\end{array}$ & $\begin{array}{l}\text { Visit to the WVGES facility } \\
\text { and museum including two } \\
\text { rounds of four rotating, } \\
\text { hands-on activities in each } \\
\text { round } \\
\text { Concepts reinforced in later } \\
\text { activities }\end{array}$ & $\begin{array}{l}\text { Science, } \\
\text { Technology, } \\
\text { Engineering, } \\
\text { Math }\end{array}$ \\
\hline $\begin{array}{l}\text { Historical } \\
\text { Geology of the } \\
\text { Appalachian } \\
\text { Mountains }\end{array}$ & $\begin{array}{l}\text { Explore the geologic history of the } \\
\text { Appalachian region. Gives the } \\
\text { campers an idea of the time and } \\
\text { processes it took to get to the } \\
\text { present landscape. }\end{array}$ & $\begin{array}{l}\text { Day trip to see major } \\
\text { geologic locations in WV } \\
\text { - Whitewater rafting on the } \\
\text { Cheat River } \\
\text { - Visit to Laurel Caverns }\end{array}$ & $\begin{array}{l}\text { Science, } \\
\text { Math, } \\
\text { Engineering }\end{array}$ \\
\hline $\begin{array}{l}\text { Geologic } \\
\text { Mapping }\end{array}$ & $\begin{array}{l}\text { The application of the knowledge } \\
\text { learned in Basic Mapping, } \\
\text { Geologic Concepts, and Historical } \\
\text { Geology. Campers learn to record } \\
\text { geologic data in StraboSpot } \\
\text { application by taking pictures, } \\
\text { adding notes, and using the built-in } \\
\text { compass to find strike and dip of } \\
\text { fold-affected rocks. }\end{array}$ & $\begin{array}{l}\text { Day trip to see major } \\
\text { geologic locations in WV } \\
\text { Deckers Creek Rail Trail } \\
\text { biking }\end{array}$ & $\begin{array}{l}\text { Science, } \\
\text { Technology }\end{array}$ \\
\hline $\begin{array}{l}\text { Hydrology and } \\
\text { Environmental } \\
\text { Geology }\end{array}$ & $\begin{array}{l}\text { Campers learn about remediation } \\
\text { efforts to clean up the effects of } \\
\text { acid mine drainage from the Cheat } \\
\text { River and its tributaries. Overview } \\
\text { of stream geomorphology, } \\
\text { ecology, and local watersheds. } \\
\text { Campers take scientific samples } \\
\text { and record data using WV } \\
\text { Department of Natural Resources } \\
\text { practices. }\end{array}$ & $\begin{array}{l}\text { - Stream assessment activities } \\
\text { (macroinvertebrate } \\
\text { collection/identification and } \\
\text { measuring pH and } \\
\text { conductivity) at Tibbs Run } \\
\text { - Visiting an acid mine } \\
\text { drainage treatment station } \\
\text { Environmental Education } \\
\text { activities }\end{array}$ & $\begin{array}{l}\text { Science, } \\
\text { Technology, } \\
\text { Engineering, } \\
\text { Math }\end{array}$ \\
\hline
\end{tabular}

\section{Analysis Overview}

This research employed a qualitative, directed content analysis approach. (Hsieh \& Shannon, 2005). Directed content analysis was used in the study because of the role of existing theories having been used to guide the coding process and focus the research questions, and due to the large amount of text and contextual information available to the researcher (Hsieh \& Shannon, 2005). This study sought to understand participants' point of view after having experienced the Appalachian GeoSTEM Camp. The researcher sought to understand the 
experience of an activity or concept from the perspective of the camp participants (Ary et al., 2009). To analyze the rich, qualitative data, and to understand the responses provided in the interviews, directed content analysis was performed (Hsieh \& Shannon, 2005; Mayring, 2000). Using Dedoose software, data from the interviews were transcribed and analyzed to look for presumed cause and presumed effect (Hsieh \& Shannon, 2005; Neuendorf, 2017). In accordance with Saldaña's (2013) coding methods and using directed content analysis (Hsieh \& Shannon, 2005), a-priori coding was conducted repeatedly to familiarize the researcher with the data and to begin to fracture the data into individually coded segments. Then, first cycle coding was carried out using empirical observation without considering a priori codes. In initial coding in the first cycle, and in accordance with directed content analysis, self-efficacy theory was used as a guide to identify key concepts and establish coding categories (Hsieh \& Shannon, 2005). The researcher focused on participant experiences and how they corresponded with Bandura's (1994) four major processes and four main sources of influence of self-efficacy. With this guiding theory, operational definitions for each category were determined (Hsieh \& Shannon, 2005). Codes were the labels created and used by the researcher in the process of identifying and indexing themes in responses while themes are the concepts pulled by the researcher from participants' perceptions and described experiences the researcher saw as relevant to the research questions (University of Huddersfield, n.d.). During the second cycle coding, the researcher employed focused coding (Saldaña, 2013) to merge and drop codes as needed while further editing codes established in the first round of coding. Focused coding led to the development of larger categories in the data and required decisions about which initial codes would be dropped (Saldaña, 2013). During both main coding cycles, the researcher concurrently maintained analytic memos. Post-coding and pre-writing transitions involved the development of main 
categories based on emergent themes (Saldaña, 2013) and themes were subsequently developed and fine-tuned. 


\section{Chapter 4: Results}

Participants interviewed included $15(83 \%)$ of the 18 adolescents who completed the program with $5(33 \%)$ males and $10(66 \%)$ females. Eighty percent of all participants were West Virginia residents. Those who identified as male had a mean age of 14.8 years-old and those who identified as female had an average age of 15 . A majority of the participants were rising tenth graders $(33 \%)$. The overall average rising grade was 10.27 with the lowest rising grade as 9 and the highest rising grade as 12 . In semi-structured interviews, campers were asked questions about their perceived self-efficacy related to Bandura's (1994) main sources of selfefficacy and his described major physiological processes through which self-beliefs of efficacy are formed. The main research questions asked if and how do the experiences at an adventure STEM camp develop perceived self-efficacy in adolescents. These questions were asked with a focus on outdoor recreation (OR) activities in which campers participated during the camp. To understand the research questions, interviewers asked participants about the specific self-efficacy sources (mastery experiences, vicarious experiences, social persuasion, and emotional physiological states) as well as the physiological processes through which self-efficacy beliefs are formed (cognitive, motivational, affective, and selection) which adolescent students may have developed and experienced in the adventure STEM setting. The goal was to understand which sources and processes were experienced and how these related to OR experiences. The data were categorized using Bandura's (1994) main sources of influence and main efficacyactivated processes. Results showed an overall change in camp participants' beliefs about their self-efficacy and that campers were able to reflect on each of their unique experiences related to the main sources and processes of self-efficacy, especially in the context of OR activities and experiences (see Table 4). 


\section{Themes for Research Question 1: How do adolescents' perceptions of their own self-efficacy change after participating in an adventure STEM summer camp?}

This research question examined campers' perceived self-efficacy after having participated in the summer camp session with a goal of understanding how changes in perceived self-efficacy occurred. This question was explored through the lens of Bandura's (1994) main sources of self-efficacy: mastery experiences, vicarious experiences, social persuasion, and emotional and physiological states, and themes were subsequently categorized using these sources. Participants were asked to recall their camp experiences in the context of their confidence in their abilities and were asked to think about these feelings before and after the camp. Interview questions were asked with a focus on OR activities that took place during the camp session as well as experiences which took place prior. The most frequently noted (15/15) theme involved mastery experiences (79). Each camper was able to point to a unique event that took place during outdoor activities in the camp session where they had to overcome obstacles through perseverant effort. The next most commonly discussed (39) theme was related to the expressed emotional and physiological states of campers. This theme showed that campers enjoyed participating in OR activities, enjoyed feelings of accomplishment related to their taskspecific abilities, and enjoyed the perceived risk and perceived potential risk associated with activity participation. The next most common theme which emerged (12/15) involved social persuasion. Of the campers who spoke about social persuasion, the prevailing theme was that their beliefs about their capabilities were influenced by camp counselors' verbal encouragement (31). The least common category spoken about by campers related to the first research question (7/15) showed that self-efficacy attitudes were impacted by vicarious experiences provided by social modeling of peers during OR activities (8). Interviewees stated that when they would see 
their peers engaging in camp activities successfully, they also felt that they had the capabilities to succeed in the same or similar situations. Themes are described in order of frequency.

\section{Mastery Experiences}

A prominent theme was that the mastery experiences which mostly ended in successes, but sometimes ended in failures, were a part of each camper's adventure STEM camp experience. The code associated with this theme was the second most common code overall across all interviewees (76) to be seen in the interviews with fifteen out of fifteen participants speaking about this theme. All fifteen participants were able to describe at least one event that took place during the camp where they had to overcome obstacles through great effort and perseverance. Additionally, many participants discussed feeling a sense of accomplishment after a mastery experience. Each of the fifteen interviewed participants had their own unique experiences of overcoming challenging OR tasks through great mental and/or physical exertion. For example, one male student, Eric, age 15, described how he overcame not believing in his rock-climbing abilities, pushed through a challenging experience, and eventually completed the task of reaching the top of the rock face successfully.

"So, at first, I thought it was beyond my physical capabilities because when I reached up, I physically could not get up. Then I realized mentally it's like I just made that little jump to get to that next arm hold then I could make it up the rock and I did that each time I found the problem and I used that to find the solution. I just made that little jump each time and slowly I made it all the way up the rock."

Another participant, Georgia, age 13, when asked if she could think of any experiences during the camp where she overcame obstacles, Georgia, recalled a specific moment during whitewater rafting where she faced a strenuous situation. She stated, “...my entire raft got flipped during 
whitewater rafting. So, you know, we had to get back in the raft and that was pretty difficult on the rapids." Another sixteen-year-old, Layla, described her feelings of validation after mastering rock climbing outdoors for the first time.

"Well, I have done rock climbing before, but not outside. And so doing it and actually accomplishing that was like justifying it, 'Okay, actually I can do this, outside, not just inside,' and maybe feel a little more confident in my abilities that - just the validation that I was like, 'Okay, you can do this."”

Another camper, Milo, age 17, described how he battled feelings of wanting to give up during a challenging task, but then continued because he believed in his abilities. He stated, "I mean obviously I thought, 'I want to quit,' but I kept pushing through it because I just thought I could do it." He later described overcoming difficulties when rock climbing that led to him feeling more comfortable with doing other tasks in the camp setting, stating,

"I did the rock climbing and it took me like fifteen minutes to get like two or three feet up in the air and once I got to a certain point, it was real easy and it gave me real confidence about this camp."

When reflecting on her experience zip-lining, Ruby, age 15, spoke about how working through practice rounds helped her trust her abilities on the full course and how after participating, she feels she has the confidence to go zip-lining in the future. She stated,

"I was just too scared to stop myself on the zip-line. We learned kind of a walk through how to stop and that was really good. I felt more confident on the zip-lines after and I would like to do the zip-lines again."

When discussing the geocaching activity, Simon, aged 13, described how it was challenging because he lacked previous experience. He said, "Whenever we did the geocaching, that was my 
first time that I had ever done that so it was tricky to understand..." He went on to say "I kind of picked it up at the end, figuring out how it works," indicating that the activity was a mastery experience for him. When discussing mastery experiences, many campers spoke about feelings of accomplishment after participation. Speaking about the biking trip and her troubles with falling many times, Zara, age 15, reflected on how she felt a sense of accomplishment after completing the task. She expressed, "I can't ride a bike...I fell three times though, but I went and did it and it was fun. It was good...well I was bruised so it was a little bit painful, but, I mean, I felt good afterwards."

\section{Vicarious Experiences}

Although Bandura (1994) discusses this topic, it was less common that campers spoke about self-efficacy attitudes being impacted by vicarious experiences provided by social models. Out of the fifteen campers interviewed, seven described experiences when vicarious experiences impacted their feelings about their abilities a total of 8 times. In the instances when camp participants spoke about this idea, they said that their peers and other people engaging in activities similar to those done at the camp successfully caused them to feel that they had the capabilities to succeed in the same or similar situations. These feelings caused campers to push themselves through specific tasks and situations.

When speaking about all of the camp activities overall and how she had newfound motivation to pursue similar activities due to her peers' successes, Marcia, age 14, said "Since I saw my friends being able to do it too, it was really helpful." Billie, age 15 , spoke about how she compared herself to professional athletes in that they were once new to whitewater rafting like she was at the time. When asked about what helped her get through the difficulties of whitewater rafting, She said “...famous athletes who also raft, they push through. They were 
once beginners like I am...I know that we all start out as beginners and I was confident." Faye, age 15, while talking about participating in all of the camp activities which she considered risky, simply stated that she would often tell herself "Other people have done it. You can do it." When discussing the difficulty he had with an unfamiliar activity, Simon, age 13, pointed out that everyone seemed to know exactly what they were doing. He went on to say that he "learned from what everyone else was doing," eventually succeeding in completing the activity and even enjoying it.

\section{Social Persuasion}

The themes related to social persuasion were centered around the verbal social influence of camp counselors. Of the fifteen campers interviewed, only two stated that during at least one point in the camp experience, their beliefs about their capabilities were influenced by those around them. For example, after pointing out that the counselors were helpful and kind throughout the camp activities, Ruby, age 15, stated that their help contributed to her confidence in her skills. She stated,

“...when I was nervous about things, they were super nice and explained the procedures or what they were doing and I really liked it. See, I [have done] things that has helped me raise confidence in skills, and had-to-be-learned new skills have also raised confidence about [doing activities]."

Faye, age 15, spoke about her fear and anxiety leading up to the zip-lining activity and how it was hard to overcome negative feelings and imagery until the counselors verbally guided her through the experience. She stated "...the counselors really coached me through it and they were really nice about it and I eventually did it so that was cool." She went on to emphasize that that experience has given her confidence to participate in the activity again in the future. 


\section{Emotional \& Physiological States}

With 103 total excerpts identified by $100 \%$ of the interviewed campers, the enjoyment of OR activities and general camp activities was the most frequent theme that arose from the data. When discussing their feelings about the camp and their abilities to succeed in camp activities, participants most often pointed out that they enjoyed participating in OR activities in general and at the camp specifically $(15 / 15 ; 103$ instances). Zara, age 15 , emphasized that she enjoyed every stage of the whitewater rafting experience. She stated, "I was excited for rafting and right before it I was still excited, and then right after, I was still excited. I had a great time.” Zara later went on to point out her enjoyment of spending time outdoors when she said "I like adventuring outdoors. I like hiking." Thirteen-year-old Georgia spoke many times about her enjoyment of OR activities. When asked how her feelings about these activities were impacted after camp participation, Georgia stated, 'I still really like them. I don't think there's anything that I had a bad experience with. I think they're all like super fun and even with the new stuff I tried because I've never gotten so far before either and they were all really, really fun." In this statement, she points out feelings of accomplishment and enjoyment in participation. Joni, age 17, expressed a change in feelings about rock climbing, saying "Before, I kind of thought it was stupid and pointless and I didn't really want to do it, but once I did it, I had a lot of fun...It was really fun and I kind of want to do it again." Fifteen-year-old Harris also commented on his enjoyment of OR activities which took place during the camp. When asked to elaborate on his feelings about these activities, Harris said, “I don't know why I love it so much, but I do. It's just the most rewarding thing I've ever done in my life. I don't know. I just love it." When asked about his general opinion of the camp activities, Simon, age 13, simply expressed "I enjoyed this camp. We did a lot of fun outdoor activities.” 
Thirteen out of the fifteen campers interviewed for the study expressed thirty-nine times how their physiological and/or emotional state impacted their feelings about the camp's activities. The first theme that emerged was that their mood (emotional) and physiological state impacted the enjoyment level of camp activities. Campers expressed feelings of excitement, exhaustion, and fear as some of the emotional and physiological states that impacted their taskspecific feelings. Most commonly, campers expressed that feeling tired or exhausted had an impact on their experience with geocaching. Fifteen-year-old Billie tied her dislike of an activity to her physiological state when she said, “I didn’t really like the geocaching [activity]. It was kind of tiring." In a similar fashion to Billie, fifteen-year-old Ruby said, "I didn’t really didn’t like the geocaching [activity] because it was right after a long hike and I was kind of tired." On the other hand, one camper felt that feeling tired helped improve his experience in the same activity. Milo, age 17, stated, "Yeah, I really liked geocaching. That was really exhausting." The second theme found in the data was related to physical capabilities. Participants expressed a total of seventeen times that their perceived and/or actual physical capabilities impacted their beliefs about their task performance during the camp. Before speaking about a mastery experience, fifteen-year-old Eric spoke about his initial feelings regarding his rock-climbing skills, saying, "So, at first I thought it was beyond my physical capabilities because like when I reached up, I physically could not get up.” Georgia, age 13, said her perceived lack of skills did not deter her from persevering. She said, "I still get really, really tired on long hikes and stuff and I hike a lot. So I feel like I don't have a lot of skill with it, but I try to improve my skill every time I go.” When speaking about whitewater rafting, seventeen-year-old Joni mentioned her task-specific confidence in her physical capabilities, saying, "I know how to wedge my foot in to the raft really well and as a sports player, I work out a lot so I feel like I was really good with the 
paddle strokes and all." Fourteen-year-old Alexandra said she did not feel pressure participating in the strenuous camp activities because of her physical capabilities. When asked to elaborate, she explained, "I'm in a pretty good physical position. Uh, yeah. I'm in shape and I can do a lot of it. It's not all that hard." Fifteen year-old Harris said that despite physical limitations, he still enjoyed participating in the camp, stating, "I've never really hurt myself doing anything like this, but definitely the physical injuries kind of put a damper on what I was able to do out here so that kind of hindered things a little bit, but I've never stopped wanting to do it."

\section{Themes for Research Question 2: How do adolescents experience changes in self-efficacy while participating in an adventure STEM summer camp?}

This research question was explored with a focus on efficacy-activated processes which impact human function (cognitive, motivational, affective, and selection) and how adolescents experienced these processes during the camp. The questions asked during the interviews focused on the camp as a whole and on the outdoor recreation activities in which campers participated (see Table 2). Participants were asked to recall and reflect on their camp experiences in the context of their confidence in their abilities and were asked to think about how these feelings may have changed due to their participation in the camp. Emergent themes were categorized using Bandura's (1977) efficacy-activated processes.

\section{Cognitive Processes}

Themes related to the effects of self-efficacy beliefs on cognitive processes were found to be very prevalent in the data, with a total of 216 excerpts involving these processes being mentioned by $100 \%$ of the campers. When asked about their cognitive processes in the context of camp and their abilities to complete tasks successfully, the most common themes in order of frequency were that interviewees often mentioned their general confidence, reflected on their 
perceived OR knowledge and skills, pointed out their expectations of how activities would go, and spoke about their perceived mental state during activities.

One-hundred percent $(15 / 15)$ of interviewed participants communicated a total of 75 times that their confidence levels impacted their beliefs about their abilities and/or their behaviors during the camp. Fifteen-year-old Eric explained that his prior experience in OR activities helped his confidence in his abilities, stating, "I just have a lot of experience with [OR activities] and it's boosted my confidence in those different recreational activities." Harris, age 15, said that he is confident in his capabilities to do OR related activities well and that there are many activities he is unsure about because he has not yet done them. He stated,

“...I'm fairly confident in the things that I do, that I know how to do and I can do it well. There are a lot of other things that I haven't really explored yet that I don't know a lot about."

Twelve out of fifteen interviewees reported an increase in confidence after participating in camp activities in 24 instances. When asked about her overall confidence after having participated in the camp program, fifteen-year-old Zara specifically pointed out a change in her confidence in her recreation activity abilities when she replied, "Yeah, I feel more confident in my abilities to do these recreational activities." She also noted that her confidence in her OR abilities was reaffirmed after having participated in the camp. When asked about changes in her confidence with her abilities, Zara stated “... I feel more confident. I mean, [the camp] just peps [my confidence] up a little, you know?" Many noted an increase in confidence in their abilities to do specific OR activities after having participated in the camp. When asked about her confidence in OR activities, fifteen-year-old, Billie commented, "[The camp] taught me some more things I didn't know I could do...like rafting and stuff...the climbing. I mean, I knew I could do it, but I 
just didn't know I had the nerves to do it." When asked the same question, Milo, age 17, indicated that troubleshooting and actually participating in rock climbing gave him confidence. In the interview he responded,

"Yeah actually. I did the rock climbing and it took me like fifteen minutes to get like two or three feet up in the air and once I got to a certain point, it was real easy and it gave me, like, real confidence about this camp."

Fifteen out of fifteen interviewed campers mentioned their perceived OR knowledge or skill a total of thirty-seven times, stating their previous experience contributed to their perceived OR skill and knowledge levels and those perceptions impacting their task-specific confidence with some mentioning their skills have improved. When asked why she thought she was a skilled outdoor adventurer, fourteen-year-old, Alexandra, pointed to her previous experience, explaining, "I have done quite a bit of adventuring outdoors...I bike a lot. I bike a lot. And, I hike sometimes, occasionally." When asked if he thought he was good at adventuring outdoors, fifteen-year-old Eric spoke about how he feels he is skilled because of his previous experience doing OR activities. He said,

"I think I was pretty good at it. I had quite a bit of experience at hiking, biking...I was still like, what's the word, an expert basically at outdoor activities because I had gone on many strenuous, highly-strenuous bikes - biking trips. Like for example, just in my neighborhood, there's a ton of really big hills. I have to get up to get back to my house, and like, my friends' houses..."

Some campers, including thirteen-year-old Georgia, suggested that their perceived OR knowledge and/or skills improved. She stated, "I think my skills with things have improved a bit because of being here and doing [OR activities] on a daily basis rather than a few times a week," 
Harris, age fifteen, pointed to his previous biking experience contributing to his OR knowledge and skills when he was asked about is OR abilities, saying "I've got bikes and I go biking all the time. I'm relatively athletic. I love doing this kind of stuff." When the interviewer went on to ask if his feelings about his abilities to adventure outdoors have changed, Harris responded, "Yeah. They’ve gotten a lot stronger." When talking about how her OR skills have changed during the camp, fifteen-year-old Faye also spoke about her biking skills. She stated, "I definitely got more confident with my starts on the bike. At first I was a little shaky, but once I got pedaling I was okay, but then by the end, I was starting off pretty okay."

Thirteen of the fifteen campers interviewed mentioned a total of 34 times that they had some sort of expectation coming into the camp and activities or specifically stated their expectations of the camp and its activities. They especially did this when discussing OR activities that are inherently challenging. Fifteen-year-old Eric explained that when his expectations were different from reality during the camp, his beliefs in his capabilities are impacted negatively. He stated,

"When going into a different certain recreation activity, I think it's going to be this exact thing and like, nothing is going to go wrong. So when something is going to go wrong, I'm like really thrown off and sometimes I'm not sure what to do."

While many campers mentioned that they had clear expectations for how their camp experience was going to be, fifteen-year-old Billie said, “Well, before I came to this camp, I didn’t know what was coming to me. I didn't know what this camp was about." Faye, age 15, spoke about her expectation that she would not have the capabilities to stop herself on the zip-line, stating, “I've been on zip-lines before, but I never had to brake myself and I usually don't like trusting myself on high impact things where I could potentially slam into a tree." When speaking about 
difficulties he faced on the Alpine Tower, Dewey, age 14, had strong expectations about his abilities stating, "Once I was down [at the bottom of the tower], I really thought I could do it, but once I got up there I knew I couldn't." He then described this situation as a bad experience which made him want to quit the activity. Ruby, age 15 , who stated she had an overall positive experience at the camp, had optimistic expectations prior to starting the session. She explained, "I had never really been camping and stuff and I was excited for that. It just seemed really fun... It was kind of like the whole thing that seemed exciting and seemed like a good thing, a good experience to have."

Of the fifteen campers interviewed, twelve spoke thirty-three times about their perceptions of their mental states during OR activities at the camp. The most prominent theme which emerged showed that although most campers' perceived mental state impacted their selfefficacy feelings and behavior during the different OR activities, they all had a wide variety of perceptions of their mental state and how they felt it impacted them. While some campers mentioned how keeping calm helped them get through stressful situations, others spoke about how their perceived control of their mental state was their biggest aid.

When asked whether she overcame any difficulties or obstacles during her camp experience, sixteen-year-old Layla said about her mental state, “...it’s just that I don’t keep myself in a mindset where I block off things. I just try to keep everything open. And if you think you can't overcome something, you're not going to do it, so I don't put that block on my mind." She indicates that she has perceived control over her mental state and an awareness of how her perceptions of her skills can impact her performance. When asked about her feelings during zip-lining, Ruby, age fifteen, described her perceived control over her mental state in 
general and when zip-lining, mentioned that she avoids thinking specifically about the risk involved and actively tries to remain calm. She stated,

"I go into this really calm state of mind. I don't really kind of get excited, I guess. I kind of get excited over things, but that's like before while I'm doing the activity... I'm just really, super calm. I'm really calm on the whole thing and I wasn't... freaking out about, 'Hey, we're a bunch of miles up in the trees.' I mean, it was kind of scary. I was kind of freaked out, but that wasn't like, I think I was in a very calm state of mind..."

When asked about how he handled the pressure and knowing that many of the activities in which he took part were risky, fifteen-year-old Eric spoke about how he always tries to remain calm and keep a composed mental state. Regarding the feelings of risk of whitewater rafting on Class 5 rapids he stated, "But I knew if I just kept my composure, and I kept on paddling, then I would be fine and wouldn't fall out the boat." He went on to elaborate about his perceptions of the impact his mental state has on his abilities during risky OR activities, saying, “...I usually just remain calm under pressure because like if you don't remain calm, then you might get a little flustered and you won't be your usual self like when doing certain physical activities like whitewater rafting, which will affect your ability to do different stuff."

\section{Motivational Processes}

Themes related to the effects of self-efficacy beliefs on motivational processes were found to be common in the data, with a total of 162 excerpts involving these processes having been mentioned by the campers. When asked about their motivational processes in the context of camp and their abilities to complete tasks successfully, the most prevalent themes in order of frequency were that interviewees described at least one perceived challenge during their camp experience, often mentioning that this perceived challenge impacted their feelings about their 
abilities. The next most prevalent themes were that campers spoke about their high motivation to participate in the camp and OR activities as well as their high motivation to participate in OR activities in the future. Lastly, participants spoke about their abilities to exercise self-influence while participating in OR activities.

Throughout the interviews, fifteen out of fifteen participants spoke at least once about how perceived challenge impacted their feelings about their OR abilities or their participation in OR activities in a variety of contexts, often simply pointing out whether they felt a specific activity was challenging or not. Perceived challenge was mentioned a total of 59 times. Georgia, age 13, implied that feeling challenged helps improve her OR abilities, stating "I still get really, really tired on long hikes and stuff and I hike a lot. So I feel like I don't have a lot of skill with it, but I try to improve my skill like every time I go.” Seventeen-year-old Joni spoke about how she felt less of a perceived challenge because her previous experience impacted her feelings about her abilities. She stated,

'I've always been like an outdoorsy person. I've always liked skiing. I've gone whitewater rafting and zip-lining before. Really, the only things that I hadn't done were like the Giant Swing, the Alpine Tower, and the rock climbing, but were still, like, fairly easy just with like my background."

Here, she implies that even though she doesn't have experience with the Giant Swing, the Alpine Tower, and rock climbing, her previous experience participating in OR activities impacts her feelings about her OR abilities and thus reduces the perceived challenge of these unknown activities.

Campers $(15 / 15)$ mentioned that they had a strong motivation to participate in OR activities a total of 61 times, often mentioning a high motivation to participate in OR activities in 
the future with 12/15 campers speaking about this theme 21 times. When asked about how the camp changed her feelings about OR activities in general, sixteen-year-old Layla said, "I think I will do [OR activities] more because I live close to all of these places so I will go out and do them probably a lot more." Then, when asked if she will do more similar activities after participating in this camp, she responded "Yes." When asked the same question about feelings about OR activities in general, Billie, age 15, replied, "I mean, maybe I could go rafting sometimes like with my family. And like, maybe I could be the raft guide." In her interview, fifteen-year-old Ruby said the experience has motivated her to continue to participate in a specific OR activity, stating, "I mean, before this I probably would never actually voluntarily go on a hike, but I think now if I found something like trails in my area or whatever area I'm in I would probably, like, go on a hike or something." Fourteen-year-old Dewey simply said, "I'd like to go whitewater rafting again." Molly, age 16, even said that she would like to do the same camp again in the future, stating, "I'd love to come back here." Fifteen-year-old Faye said that even though she was tired from the day's activities, she was still highly motivated to participate in whatever activity was planned next, thus implying a high motivation to participate in OR activities in the future. She said, "I was a little tired after whitewater rafting, but I was still up for whatever we were going to do next..."

Another theme emerged when all of the interviewed campers described how they felt they could exercise self-influence or their perceived abilities to enact an action. Fifteen out of fifteen interviewed participants spoke a total of 41 times about their perceived abilities in exercising self-influence during the camp and while participating in OR activities. Some campers spoke generally about their coping abilities related to OR activities. For example, fifteen-year-old Zara, simply said, "I think I can handle pressure well," when asked how she felt 
about the inherent risk of OR activities in which she participated. Seventeen-year-old Joni explained what she does in stressful situations. She explained,

"I kind of like just take a second to breathe and look at like my options. If I was injured like when I've got an injury skiing, I kind of assess how bad the injury is and if it's just kind of like a little pain, I keep going unless it gets worse. So, I just kind of take a minute or two to assess the situation and see where to go from there.

After being asked about his feelings about his coping abilities, fifteen-year-old Harris pointed to his own self-influence when he said "I run a lot of scenarios in my head all the time... even though it's scary, we're going to get through it and that's what I like about it. It's like, it's in your hands whatever you do." Some campers, such as fifteen-year-old Eric, spoke about their perceived abilities to exercise self-influence in specific OR activities and situations. Eric talked about his efforts during a mastery experience when he stated,

“Then I realized mentally it's like I just made that little jump to get to that next arm hold then I could make it up the rock and I did that each time I found the problem and I used that to find the solution. Like, I just made that little jump each time and slowly I made it all the way up the rock."

Fifteen-year-old, Marcia talked about how even though she did not feel confident in her abilities while rock climbing and climbing the Alpine Tower, she was still able to influence her thoughts and feelings. She stated,

“...I think in both, I was really relying on myself and like, I have to be able to trust myself in order to get it done. Like it was just kind of hard to like remember that I am in control and that, like, if I freak out like I'm not going to do as well." 


\section{Affective Processes}

Themes related to the impacts of self-efficacy beliefs on affective processes were found to be somewhat common in the data, with a total of 96 excerpts involving these processes having been mentioned by the interviewed campers. When speaking about their affective processes in the context of camp and their abilities to complete tasks successfully, the most prevalent themes in order of frequency were that similar trends in perceived coping abilities/skills were described by interviewees $(15 / 15)$ and that campers stated that they enjoyed the inherent risk associated with the OR activities in which they participated (11/15).

Trends were found in interviewed campers' perceptions of their coping abilities and skills while participating in OR activities. These trends include staying calm, keeping a clear mind, participants listening to those around them, and participants telling themselves to push through challenging situations. Fifteen out of fifteen interviewed campers mentioned these perceptions a total of 57 times. Sixteen-year-old Layla stated several times that she tries to keep a clear mind to calm herself down during stressful OR situations, explaining that she utilizes meditating or, “...clearing my mind. I don't really do the deep breath thing, but just clearing my mind and blocking everything out and becoming centered." Several campers, such as fifteen-year-old Eric, pointed to staying calm when asked what they do to help cope with pressure during OR activities. Eric stated, "I usually just remain calm under pressure because like if you don't remain calm, then you might get a little flustered and you won't be your usual self like when doing certain physical activities like whitewater rafting, which will affect your ability to do different stuff." Of the campers that mentioned "pushing through" as a part of their perceived coping abilities and skills, fifteen-year-old, Zara highlighted this when she spoke about how she has to finish a challenging OR activity once she starts it, stating, "I guess I have to reassure 
myself. It's like you're already halfway there so why stop now? Yeah. So, I just like, I have this tendency to, like finish things that I already started so I want to finish that thing." Similarly, when asked how he deals with challenging OR activities, fourteen-year-old Dewey simply said, "I try to push myself more." After being asked the same question, Milo, age 17, stated, "I mean obviously I thought, "I want to quit," but I kept pushing through it because I just thought I could do it." Some campers spoke about how they cope with stressful OR challenges by listening to experts in the situation. When asked about how she handles these situations, fifteen-year-old, Billie explained that she copes by leaning on OR expert guides, explaining, "I don't know. Like, just like, just to get out there and try to do your best and know that it will be alright and like, nothing will happen and that the guides are there to tell you what to do."

During interviews, campers mentioned their perceived safety and risk somewhat frequently with eleven out of fifteen participants speaking about the subject 36 times total. The most common theme to occur was that Campers enjoyed the perceived risk associated with the camp OR activities. When asked about how he felt doing OR activities before completing the camp session, Eric, age 15, said,

"Whitewater rafting. I thought it would be, like, much scarier and dangerous, but I ended up staying in the boat the entire time and I actually enjoyed it quite a bit even though the water was moving faster than usual."

After being asked what her favorite part of the camp was, fifteen-year-old Ruby said she enjoyed the activities that involved the most risk. She expressed, "Like, they're really inherently dangerous things that we were doing and there is safety stuff and uh, yeah, they are definitely my favorite." Similarly, thirteen-year-old Georgia explained, "I feel like everything that is really, really fun has some type of risk... Whitewater rafting, people have died from that before, but I 
don't think that it's a reason to get, like, super scared over it because it can be scary, but it's also a whole lot of fun." Joni, age 17, was more specific about why she enjoys risk associated with outdoor recreation activities, saying "I kind of like the risk and danger factor. I just kind of have that like [adrenaline], I love the [adrenaline] rush.” Sixteen-year-old Layla spoke about her enjoyment of feeling accomplishment as well as an enjoyment of the associated risk.

"When we were rock-climbing, when I got down, it was a really good feeling that I had accomplished something, and I like that feeling of accomplishment when I do something dangerous or risky, I guess."

\section{Selection Processes}

The themes which involved the impacts of self-efficacy beliefs on selective processes found in the data to be somewhat common in the data, with a total of 112 excerpts involving these processes having been mentioned by one-hundred percent of the interviewed campers. When speaking about their selective processes in the context of camp and their abilities to complete tasks successfully, the most prevalent themes in order of frequency were first that campers pointed to previous experiences when thinking about their abilities and in making choices during OR activities at the camp (15/15) and second that campers (14/15) stated that already had a high interest in OR activities prior to coming to the camp which impacted their decision to participate and their feelings about participating in camp activities.

The most common theme in the category of selection processes is that participants discussed previous OR experiences when thinking about their abilities and while making decisions during specific OR activities during the camp. All fifteen participants spoke about this theme a total of 57 times. For example, thirteen-year-old, Simon, pointed to his experience in specific activities impacting his confidence in his ability to participate in said activities during 
camp. He claimed that he was assured of his abilities in "Rock climbing, zip-lining, and Alpine Tower," after being asked in which activities he was most confident. When asked why he felt confident in those OR activities, he replied 'Because I've done many ropes courses and I've done zip-lining and I really enjoy rock climbing," indicating his previous experiences as a source of reassurance. When asked to elaborate on why he claimed to feel confident in participating in difficult OR activities, Eric, aged 15, said, “I think it's mainly because I just had a lot of experience with outdoor activities, like, I spend a lot of time outdoors, like, running, hiking, biking, playing basketball, football... I just have a lot of experience with that and it's boosted my confidence in those different recreational activities." In response to a question about why she did not feel very challenged doing rock climbing at the camp, fifteen-year-old, Zara, spoke specifically about previous experiences impacting how she handled the same activity at camp, stating,

"I already do rock climbing, in a sense... I go to the Rec Center a lot so sometimes we go, like, bolting in that little cave... So, just like going to Coopers Rock and doing that rock climbing [at camp], I did both of the hardest levels. I completed them both in like a sensible amount of time, like two minutes for each... I already felt very comfortable with rock climbing. It was just like a slightly different experience doing it on real rocks."

Seventeen-year-old, Joni, claimed that even though she did not have a lot of experience in one activity, her previous experience in other challenging OR activities made her feel more confident at camp. After being asked about why she felt confident in these other activities, she replied, 'I'm not that good at rock climbing yet, but I feel like just since I've had a little experience with some of the things, I'm pretty good." When asked about why she thought of herself as someone 
who is good at adventuring outdoors, fourteen-year-old, Alexandra, said "I have done quite a bit of adventuring outdoors...I bike a lot. I bike a lot. And, I hike sometimes, occasionally."

The second most prevalent theme related to selection processes involved the interest levels of campers in OR activities. Fourteen of fifteen participants spoke 55 times about how they had a high interest in OR activities prior to coming to the camp, often speaking about how this interest impacted their behaviors during activities. For example, some mentioned that this interest is what caused them to choose their camp participation in the first place. Fifteen-yearold, Billie explained that she is drawn to OR activities, stating,

“I'm a crazy girl and like, I like climbing things and I feel like [friends and family] would probably say the same thing, like, I seem like a person who would love to be outside and... loves climbing things and having, I mean like, a dare-devil I guess you would say. Stuff like that... I really like climbing... I really enjoy the rafting."

Similarly, when asked what motivated her to go to the camp, fifteen-year-old, Ruby, simply stated, "Well, I suppose it was the outdoor activities." When asked about how he felt about challenging OR activities prior to coming to the camp, fifteen-year-old Harris indicated his interest in these activities is also why he chose to come to the camp, stating, "I loved it and that's most the reason that I wanted to come. That's what I wrote about in my scholarship essay. I really loved it." Layla, aged 16, also spoke about her enjoyment of and interest in OR activities when she said, "I mean, I like being outside. I like doing sports and all the outdoor activities. Just all of it. I really enjoy it and it makes me very excited when I do it..." When asked about what they thought their friends and families would say about the campers' feelings toward OR activities, many participants, such as fifteen-year-old Eric answered that these groups would 
speak to their high interest in such activities. He explained that they would say, "I would be good at that and it is something that I would be interested in."

Table 4: Theme Overview

\section{Research Question: How do adolescents' perceptions of their own self-efficacy related to outdoor recreation activities change after participating in an adventure STEM summer camp?}

\begin{tabular}{|c|c|c|}
\hline Theme & $\begin{array}{l}\text { Example of Datum Supporting the } \\
\text { Theme }\end{array}$ & $\begin{array}{l}\text { Researcher's Interpretive } \\
\text { Summary }\end{array}$ \\
\hline
\end{tabular}

Mastery Experience

\begin{tabular}{ll}
\hline $\begin{array}{l}\text { Mastery experiences which mostly } \\
\text { ended in successes, but sometimes } \\
\text { ended in failure, were a part of } \\
\text { each camper's adventure STEM } \\
\text { camp experience. }\end{array}$ & $\begin{array}{l}\text { Times Coded: } 76 \\
\text { Participants: } 15 / 15\end{array}$ \\
& $\begin{array}{l}\text { Milo, age 17: "I did the rock climbing } \\
\text { and it took me, like, fifteen minutes to } \\
\text { get like two or three feet up in the air } \\
\text { and once I got to a certain point, it was } \\
\text { real easy and it gave me real } \\
\text { confidence about this camp." }\end{array}$
\end{tabular}

Mastery experiences are an integral part of how self-efficacy beliefs and perceptions were formed due to the camp.

\section{Vicarious Experience}

\begin{abstract}
The few camp participants who
said that their peers and other people engaging in activities similar to those done at the camp successfully caused them to feel that they had the capabilities to succeed in the same or similar situations.
\end{abstract}

Times Coded: 8

Participants: 7/15
Marcia, age 14: "Since I saw my friends being able to do it too, it was really helpful."
Seeing peers do well at something gave participants OR task-specific self-confidence. This scenario can often be presented in the adventure STEM camp setting.

Emotional \& Physiological State

\footnotetext{
Campers enjoyed participating in OR activities in general and at the camp specifically.
}

Times Coded: 103

Participants: 15/15

Georgia, age 13: "I still really like [OR activities]. I don't think there's anything that I had a bad experience with. I think they're all, like, super fun and even with the new stuff I tried because I've never gotten so far before
The enjoyment levels of the campers while they participated in the camp led to more positive feelings about themselves in the roles they fulfilled during activities, thus impacting their OR self-efficacy perceptions. 


\begin{tabular}{ll}
\hline & $\begin{array}{l}\text { either and they were all really, really } \\
\text { fun." }\end{array}$ \\
$\begin{array}{ll}\text { Mood (emotional) and } \\
\text { physiological state impacted the } \\
\text { participants' enjoyment levels of } \\
\text { camp activities. }\end{array}$ & $\begin{array}{l}\text { Times Coded: } 39 \\
\text { Participants: } 13 / 15\end{array}$ \\
& $\begin{array}{l}\text { Billie, age 15: "I didn't really like the } \\
\text { geocaching [activity]. It was kind of } \\
\text { tiring." }\end{array}$ \\
$\begin{array}{l}\text { Participants' perceived and/or } \\
\text { actual physical capabilities } \\
\text { impacted their beliefs about their } \\
\text { task-specific performance during } \\
\text { the camp. }\end{array}$ & $\begin{array}{l}\text { Times Coded: } 17 \\
\text { Participants: } 9 / 15\end{array}$ \\
& $\begin{array}{l}\text { Eric, age } 15: \text { "So, at first I thought it } \\
\text { was beyond my physical capabilities }\end{array}$ \\
because like when I reached up, I \\
physically could not get up."
\end{tabular}

The impact on enjoyment level therefore affected the campers' perceptions of themselves in participation and consequently their self-efficacy beliefs.

Encountering situations where physical capabilities needed to be assessed forced campers to think about abilities and therefore impacted self-efficacy beliefs.

\section{Research Question: How do adolescents experience changes in self-efficacy related to outdoor recreation activities while participating in an adventure STEM summer camp?}

\begin{tabular}{|c|c|c|}
\hline Theme & Datum Supporting the Theme & $\begin{array}{l}\text { Researcher's Interpretive } \\
\text { Summary (aka discussion) }\end{array}$ \\
\hline
\end{tabular}

Cognitive Processes

Interviewed participants
communicated that confidence
levels impacted their beliefs about
their abilities and/or their
behaviors during the camp.

Interviewees reported an increase in confidence after participating in camp activities.

Campers spoke about how their previous experience contributed to their perceived OR skill and knowledge levels and those perceptions impacting their taskspecific confidence with some mentioning that their skills have improved.
Times Coded: 75
Participants: $15 / 15$

Harris, age 15: “...I'm fairly confident in the things that I do, that I know how to do and I can do it well. There are a lot of other things that I haven't really explored yet that I don't know a lot about."

Times Coded: 24

Participants: 12/15

Billie, age 15: "[The camp] taught me some more things I didn't know I could do...like rafting and stuff...the climbing. I mean, I knew I could do it, but I just didn't know I had the nerves to do it."

Times Coded: 37

Participants: 15/15

Eric, age 15: "I think I was pretty good at it. I had quite a bit of experience at hiking, biking...I was still like, what's the word, an expert basically at outdoor activities because I had gone on many
The camp setting caused campers to think often about whether or not they felt confident enough to complete a task.

Campers reported that the specific adventure STEM camp setting increased their confidence in themselves in general and in their specific OR abilities. In short, participation in the camp caused an increase in factors directly related to ORrelated self-efficacy.

Campers believe that experience in OR activities causes an increase in OR knowledge and skill and that participation in the camp caused an increase in these factors for themselves. This idea demonstrates that the adventure STEM camp setting improves 
Campers said that they either had some sort of expectation of the camp and what camp activities would be like, or specifically stated their expectations of the camp and its activities. They especially did this when discussing outdoor recreation activities that are inherently challenging.

Campers' perceived mental state impacted their self-efficacy feelings and behavior during the different OR activities in which they participated. They all had a wide variety of perceptions of their mental state and how they felt it impacted them. While some campers mentioned how keeping calm helped them get through stressful situations, others spoke about how their perceived control of their mental state was their biggest aid. strenuous, highly-strenuous bikes biking trips.

Times Coded: 34

Participants: 13/15

Ruby, age 15: "I had never really been camping and stuff and I was excited for that. It just seemed really fun... It was kind of like the whole thing that seemed exciting and seemed like a good thing, a good experience to have."

Times Coded: 33

Participants: $12 / 15$

Layla, age 16: “...it's just that I don't keep myself in a mindset where I block off things. I just try to keep everything open. And if you think you can't overcome something, you're not going to do it, so I don't put that block on my mind."

Motivational Processes their perceptions about ORrelated self-efficacy beliefs.

This theme further illustrates that the adventure STEM camp process fosters reflection about self-efficacy beliefs related to OR activities.
The setting put participants in situations where they reflected on their mental states during stressful and risky OR activities. The wide variety of feelings about their mental states during these activities were all described as impacting their beliefs about task-specific confidence.
Perceived challenge impacted participants' feelings about their OR abilities or their participation in OR activities in a variety of contexts, often simply pointing out whether they felt a specific activity was challenging or not.
Times Coded: 59

Participants: $15 / 15$

Zara, age 15: "Yeah, when we were pedaling uphill, since I was using more of my muscle, I felt more controlled. Like when I was pedaling downhill, I like being able to control everything. So, it was, like, harder for me."

Times Coded: 61

Participants: $15 / 15$

Times Coded: 21

Participants: $12 / 15$

Ruby, age 15: "I mean, before this I probably would never actually voluntarily go on a hike, but I think now if I found something like trails in my area or whatever area I'm in I
Feeling challenged or not challenged was an important factor in participants' experience during the camp which impacted motivation to participate in OR activities. Campers sought out challenges and often exerted greater effort when they were attempting to master a given challenge, indicating a strong belief in their capabilities (Bandura, 1994).

This described strong motivation to participate in OR activities in general and after having participated in the camp indicates an increase in OR activity-related self-efficacy. This increase can be attributed to the often mentioned selfsatisfying experiences which the campers had during the camp which impacted their motivation 
Participants spoke about their perceived abilities in exercising self-influence during the camp session and while participating in OR activities. would probably, like, go on a hike or something."

Times Coded: 41

Participants: $15 / 15$

Harris, age 15: "I run a lot of scenarios in my head all the time... even though it's scary, we're going to get through it and that's what I like about it. It's like, it's in your hands whatever you do." to participate in similar activities in the future (Bandura, 1994).

The camp provided a setting in which campers reflected on their abilities to exercise self-

influence in OR situations on their own. These feelings impact motivation to participate in goals and tasks and are therefore integral to the development of self-efficacy beliefs (Bandura, 1994).

Affective Processes

Trends were found in interviewed campers' perceptions of their coping abilities and skills while participating in OR activities. These trends include staying calm, keeping a clear mind, participants listening to those around them, and participants telling themselves to push through challenging situations.

Campers enjoyed the perceived risk associated with the camp OR activities.

\section{Times Coded: 57 \\ Participants: 15/15}

Marcia, age 15: “...I think in both, I was really relying on myself and like, I have to be able to trust myself in order to get it done. Like it was just kind of hard to like remember that I am in control and that, like, if I freak out like I'm not going to do as well."

Times Coded: 36

Participants: 11/15

Georgia, age 13: "I feel like everything that is really, really fun has some type of risk... Whitewater rafting, people have died from that before, but I don't think that it's a reason to get, like, super scared over it because it can be scary, but it's also a whole lot of fun."
Campers were given an opportunity to reflect on their perceived coping self-efficacy which "regulates avoidance behavior as well as anxiety arousal (Bandura, 1994)." Participants interviewed showed a strong sense of self-efficacy in this area, therefore demonstrating their likelihood of taking on challenging and threatening OR activities such as those experienced in the camp (Bandura, 1994).

The enjoyment of perceived risk associated with camp activities further demonstrates the motivations of participants. The inherent challenge of risky activities is enjoyed because it is a part of the self-satisfying reaction to success in one's performance (Bandura, 1994). In other words, campers enjoy that they succeeded in risky challenges during the camp, and this enjoyment served as a motivation process through which self-efficacy beliefs can be formed.

\section{Selection Processes}

Participants discussed previous OR Times Coded: 57

experiences when thinking about their abilities and while making
Participants: 15/15
Bandura (1994) pointed out that the processes of creating selfefficacy beliefs involve 
decisions during specific OR activities during the camp.
Eric, age 15:

"I think it's mainly because I just had a lot of experience with outdoor activities, like, I spend a lot of time outdoors, like, running, hiking, biking, playing basketball, football... I just have a lot of experience with that and it's boosted my confidence in those different recreational activities."

Participants had a high interest in OR activities prior to coming to the camp, often speaking about how this interest impacted their behaviors during activities. Some mentioned that this interest is what caused them to choose their camp participation in the first place.
Times Coded: 55

Participants: $15 / 15$

Layla, age 16: "I mean, I like being outside. I like doing sports and all the outdoor activities. Just all of it. I really enjoy it and it makes me very excited when I do it..." experiences which help people develop knowledge and skill and, consequently, impact beliefs about what they can accomplish. Campers were able to point to previous OR experiences during activity participation during the camp.

Not only does this described high interest indicate strong selfefficacy beliefs in the campers, it can also be seen as a means of motivation for continued participation when faced with challenges throughout the program (Bandura, 1994). 


\section{Chapter 5: Discussion}

All of the interviewed adventure STEM camp participants pointed to self-efficacy-related experiences unique to them which took place during outdoor recreation (OR) activities in the camp session, and described their perceptions of the subsequent physiological processes related to those experiences. These results indicate that each camper experienced an increase in selfefficacy in their abilities related to OR. The experiences that participants described aligned with Bandura's (Bandura, 1977) main sources of self-efficacy and the physiological processes reported fit with his described processes through which self-efficacy beliefs are formed. Rogoff et al. (Rogoff et al., 2016) suggested that participation in informal learning can lead to the development of one's identity. The adventure STEM camp studied appeared to be an effective place to foster personal growth by way of establishing and improving perceptions about ORrelated task-specific confidence for these adolescents. Using Bandura's described physiological processes by which self-efficacy beliefs are formed (1994), the data collected demonstrated that, although participants experienced changes in their self-efficacy during their participation in unique ways, they all shared overarching similarities in these processes. Notably, the following factors most often impacted all interviewed participants' perceptions and beliefs about their ORrelated self-efficacy: mastery experiences, confidence levels, the perceived challenge of activities, self-described strong motivation levels to participate in OR activities, coping abilities related to difficult or risky OR activities, previous experiences, and a high interest in OR activities prior to attending the camp.

The curriculum used in this particular adventure STEM camp setting utilized Kolb's (1984) Experiential Education Theory. The rich data collected indicated an increase in participant OR-related self-efficacy due to a variety of factors and experiences. This result was 
expected given that empirical research findings regarding the utilization of experiential learning in educational and vocational programming have shown increases in participant self-efficacy beliefs when this theory is applied (Banfield \& Wilkerson, 2014; Esters \& Retallick, 2013; Watters et al., 2015). The summer camp setting is beneficial in providing opportunities for personal growth (Garst \& Whittington, 2020) and based on the findings of this study, the adventure STEM camp setting was an excellent environment for improving adolescent participants' OR-related self-efficacy. Moreover, this setting provides myriad positive affective and cognitive outcomes including identity development, increased self-confidence, resilience, intrinsic motivation, autonomy, and well-being (Duerden et al., 2009; Houge Mackenzie \& Hodge, 2019). Along with the benefits of informal learning, experiential education, and outdoor recreation all being present in the adventure STEM experience, this study shows that improved self-efficacy related to OR activity performance is another outcome of participation in this setting. The results of this study demonstrate the potential effectiveness of systemically blending formal learning, informal learning, and outdoor adventure education experiences together. The themes found in the data give insight into the benefits of adventure STEM programming and can provide program managers of the Appalachian GeoSTEM Camp with insight to improve future camp sessions.

\section{Themes}

Mastery experiences which mostly ended in successes, but sometimes ended in failure (Bandura, 1994), were a part of each camper's adventure STEM camp experience. Therefore, these experiences were an integral part of how self-efficacy beliefs and perceptions were formed due to camp participation. The prevalence of this experience reported in the data demonstrates that programs like the Appalachian GeoSTEM Camp setting are a great environment for personal 
growth while learning important STEM topics. Informal learning, outdoor recreation, and summer camp programs provide plenty of opportunities for mastery experiences to occur so this outcome was expected after having participated in this adventure STEM camp (Bell et al., 2016; Duerden et al., 2009; Hogue Mackenzie \& Hodge, 2019; Lane et al., 2013; Locklear, 2013; Wilson et al., 2019).

The few camp participants who spoke about the vicarious experiences provided by social models said that their peers and other people engaging in activities similar to those done at the camp successfully caused them to feel that they had the capabilities to succeed in the same or similar situations. In short, seeing peers do well at something gave some participants taskspecific self-confidence. Because of the camp setting's intrinsically social quality, this scenario can often be presented in the specific camp setting and these results show that this can also be seen in the adventure STEM camp setting (Garst \& Whittington, 2020; Wilson et al., 2019).

Campers enjoyed participating in OR activities in their lives and at the camp specifically. The enjoyment levels of the campers while they participated in the camp led to more positive feelings about themselves in the roles they fulfilled during activities. Bandura (1994) demonstrated that enjoyment of an activity can often lead to a higher motivation to participate in said activity which can then lead to improved self-efficacy beliefs. Fun and enjoyment often go hand-in-hand with the camp setting due to friend-making, achievement, positivity, and safety (Garst \& Whittington, 2020) as well as the many naturally fun OR activities in which campers participate. Combining this inherently fun setting with difficult school topics that are often taught with rigidity (Ngaka et al., 2012) may help improve the learning experience and possibly provide opportunities for increased motivation to learn about a challenging topic and/or increased self-efficacy beliefs regarding a challenging topic. 
As Bandura suggests (1994), mood, or emotional and physiological state, impacted the participants' enjoyment level of camp activities and therefore the campers' perceptions of themselves in participation. The mood of campers would often lead them to make decisions about their performance in OR activities, with campers who were in a bad mood or who were tired enjoying certain activities less. Although it was only mentioned a handful of times, feeling fatigued and therefore not enjoying an activity could have prevented those campers from pushing themselves to challenge themselves in an activity and therefore may have missed out on opportunities to improve self-efficacy beliefs. On the other hand, one camper mentioned that feeling fatigued improved his experience of an activity because he had to challenge himself even more. Due to the inherently physical nature of OR activity participation and the summer camp setting, as well as the setting's positive, fun, challenging qualities (American Camp Association, 2005; Garst et al., 2001; Martin, 2018; Mackenzie et al., 2018; Mutz \& Müller, 2016; Passarelli et al., 2010), this fatigue was not unexpected.

Participants' perceived and/or actual physical capabilities impacted their beliefs about their task-specific performance during the camp. Encountering situations where physical capabilities needed to be assessed forced campers to think about their OR abilities. This was a common occurrence at the camp as activities such as rock climbing, whitewater rafting, and ropes courses happened daily. This reflection on OR abilities therefore impacted participants' self-efficacy beliefs and sometimes their behaviors. This theme demonstrates yet another opportunity for task-specific self-confidence development provided by the unique adventure STEM camp setting. Similar to mood impacting participants' enjoyment of activities, the quality of the adventure STEM program being inherently physical meant that this outcome was not 
unexpected (American Camp Association, 2005; Garst et al., 2001; Martin, 2018; Mackenzie et al., 2018; Mackenzie \& Eitel, 2017; Mutz \& Müller, 2016; Passarelli et al., 2010).

Interviewed participants communicated that confidence levels impacted their beliefs about their abilities and/or their behaviors during the camp. According to the interviewees, the camp setting caused campers to think often about whether or not they felt confident enough to complete a task and why. Furthermore, interviewees reported an increase in confidence after participating in camp activities. Campers reported that the specific camp setting increased their confidence in themselves in general and in their specific OR abilities. In short, participation in the adventure STEM camp caused an increase in factors directly related to both general selfefficacy and OR-related self-efficacy.

As Bandura's (1994) theory indicates, campers spoke about how their previous experience contributed to their perceived OR skill and knowledge levels and those perceptions impacting their task-specific confidence with some mentioning that their skills have improved. Campers believed that experience in OR activities caused an increase in OR knowledge and skill and that participation in the camp caused an increase in these factors for themselves. This idea demonstrates that the adventure STEM camp setting improved their perceptions about ORrelated self-efficacy beliefs such as perceived skill and knowledge. Due to its utilization of informal learning techniques, the summer camp setting, and outdoor recreation activities (American Camp Association, 2005; Garst et al., 2001; Martin, 2018; Mackenzie et al., 2018; Mackenzie \& Eitel, 2017; Mutz \& Müller, 2016), this adventure STEM camp setting provided myriad novel opportunities for campers to use knowledge and confidence gained from previous experiences throughout the program. 
Campers said that they either had some sort of expectation of the camp and what camp activities would be like, or specifically stated their expectations of the camp and its activities. They especially did this when discussing outdoor recreation activities that are inherently challenging. This theme further illustrates that the adventure STEM camp process fosters reflection about self-efficacy beliefs related to OR activities.

Campers' perceived mental state impacted their self-efficacy feelings and behavior during the different OR activities in which they participated. This theme is in line with Bandura's (1994) statements about the role that mental state has in. Participants all had a wide variety of perceptions of their mental state and how they felt it impacted them. While some campers mentioned how keeping calm helped them get through stressful situations, others spoke about how their perceived control of their mental state was their biggest aid. The setting put participants in situations where they reflected on their mental states during stressful and risky OR activities and had to practice skills related to these states. The wide variety of feelings about their mental states during these activities were all described as impacting their beliefs about taskspecific confidence.

Perceived challenge impacted participants' feelings about their OR abilities or their participation in OR activities in a variety of contexts, and they often simply pointing out whether they felt a specific activity was challenging or not. Feeling challenged or not challenged was an important factor in participants' experience during the camp which impacted motivation to participate in OR activities. Campers sought out challenges and often exerted greater effort when they were attempting to master a given challenge, indicating a strong belief in their capabilities (Bandura, 1994). Opportunities for challenging moments are extremely common in the adventure camp setting (American Camp Association, 2005; Garst et al., 2001). 
Campers mentioned they had a strong motivation to participate in OR activities, often mentioning a high motivation to participate in similar activities in the future. This described strong motivation to participate in OR activities in general and after having participated in the camp indicates an increase in OR activity-related self-efficacy. This increase can be attributed to the often-mentioned self-satisfying experiences which the campers had during the camp which impacted their motivation to participate in similar activities in the future (Bandura, 1994). This increase can also be compared to other affective and cognitive impacts on those who participate in informal learning, outdoor recreation, and summer camp programming (Bell et al., 2016; Duerden et al., 2009; Houge Mackenzie \& Hodge, 2019; Lane et al., 2013).

Participants spoke about their perceived abilities in exercising self-influence during the camp session while participating in OR activities. The camp provided a setting in which campers reflected on their abilities to exercise self-influence in OR situations on their own. These feelings impact motivation to participate in goals and tasks and are therefore integral to the development of self-efficacy beliefs (Bandura, 1994).

Trends were found in interviewed campers' perceptions of their coping abilities and skills while participating in OR activities. These trends include staying calm, keeping a clear mind, participants listening to those around them, and participants telling themselves to push through challenging situations. Campers described having been given opportunities to reflect on their perceived coping self-efficacy, which "regulates avoidance behavior as well as anxiety arousal (Bandura, 1994)," during the camp. Participants interviewed showed a strong sense of selfefficacy in this area, therefore demonstrating their likelihood of taking on challenging and threatening OR activities such as those experienced in the camp (Bandura, 1994). 
Campers enjoyed the perceived risk associated with the camp OR activities. The enjoyment of perceived risk associated with camp activities further demonstrates the motivations of participants. The inherent challenge of risky activities is enjoyed because it is a part of the self-satisfying reaction to success in one's performance (Bandura, 1994). In other words, campers enjoy that they succeeded in risky challenges during the camp, and this enjoyment served as a motivation process through which self-efficacy beliefs can be formed.

Participants discussed previous OR experiences when thinking about their abilities and while making decisions during specific OR activities during the camp. Bandura (1994) pointed out that the processes of creating self-efficacy beliefs involve experiences which help people develop knowledge and skill and, consequently, impact beliefs about what they can accomplish. Campers were able to point to previous OR experiences during activity participation during the camp. It may also be inferred that campers can use their experiences in the adventure STEM camp in the future when making decisions about similar OR activity participation.

Participants had a high level of interest in OR activities prior to coming to the camp, often speaking about how this interest impacted their behaviors during activities. Some mentioned that this interest is what caused them to choose their camp participation in the first place. Not only does this described high interest indicate strong self-efficacy beliefs in the campers, it can also be seen as a means of motivation for continued participation when faced with challenges throughout the program (Bandura, 1994).

\section{Limitations}

Several limitations of the study are noteworthy and are important to consider. Although all of the campers were adolescents, this convenience sample is not representative of the adolescent population. Nonprobability sampling techniques such as convenience sampling are 
subjective in nature and are therefore not a good representative of the population (Ilker Etikan et al., 2016). Additionally, there was no control group utilized for the study. A majority of the campers were already experienced in OR activities and were eager to experience the unique activities the program provided. Additionally, over half of the campers were from the same region: West Virginia. Although the data is not generalizable to the larger adolescent population (Ilker Etikan et al., 2016), the purpose of this qualitative study was to gain a greater understanding of the topic (Mayring, 2000). With appropriate methodology, future studies may generate generalizable results.

\section{Conclusion}

In campers' reflections about their experiences, a clear and apparent change in perceived self-efficacy and task-specific confidence related to OR activity participation occurred after having participated in the adventure STEM program studied. The adventure STEM camp studied has proven to be an effective place to foster personal growth by way of establishing and improving perceptions about OR-related task-specific confidence for the studied group of adolescents. In alignment with Bandura's described physiological processes by which selfefficacy beliefs are formed (1994), the results show that participants experienced changes in their self-efficacy during their participation in unique ways, but also all shared overarching similarities in these processes. The most common overarching themes which impacted all interviewed participants' perceptions and beliefs about their OR-related self-efficacy involved mastery experiences, confidence levels, the perceived challenge of activities, self-described strong motivation levels to participate in OR activities, coping abilities related to difficult or risky OR activities, previous experiences, and a high interest in OR activities prior to attending the camp. 
The outcomes of this study can be useful in adding to the understanding of adventure STEM program impacts on adolescents and will provide camp managers with information that could potentially improve future Appalachian GeoSTEM Camp sessions. Some recommendations may include placing a greater emphasis on reflection after participation in an activity to allow for campers to observe and contemplate feelings related to their self-efficacy perceptions. This added reflection is also beneficial in solidifying learned concepts in the process of experiential learning (Kolb, 1984). Moreover, the opportunities for reflection of these experiences allowed for campers to explore their beliefs and feelings about their abilities and confidence related to OR activities. Program managers could also put more of an emphasis on activities in which mastery experiences are formed such as whitewater rafting, zip-lining, and rock climbing. Lastly, program managers can add into the curriculum a requirement by Adventure WV leaders to teach participants about coping skills during high-stress OR activities. Based on the described perceived coping abilities and skills seen in the data, campers' experiences and self-efficacy perceptions improved when they felt confident in their coping abilities and skills during the camp. Linking these strategies to curriculum can help campers increase self-efficacy perceptions in future sessions of the camp program. 


\section{Appendices}

\section{Appendix A: Interview Instrument}

Camper ID \#:

Date:

Time:

Interviewer:

Participant Interview Protocol

Appalachian GeoSTEM Camp, 2019

\section{Interviewer Notes}

- Prior to the interview, review the selected responses from the specific camper's survey that will be asked about in the Pt. II of the survey.

- Use the iPhone Voice Memo App to record the interviewee's responses. Double and triple check that it is recording! Do a test run before the interview to make sure it works!

\section{Introduction}

- "First off, thank you so much for participating in this interview. Your answers will be used as a part of my thesis research and will contribute to a better understanding of the impacts that these types of camps may have."

- "Anything you say in this interview will be absolutely confidential and anonymous. Your name will never be attached to your answers. Please take your time and answer these questions as honestly as you can. If you do not feel comfortable answering any of these questions, you can skip them."

- "This interview is entirely voluntary. You can opt not to take it and can stop the interview at any time."

- (Explain the purpose of the interview):

○ "I'm looking to understand your feelings about your confidence in your ability to do outdoor adventure-related activities."

- "I also want to see if those beliefs or feelings have changed after participating in this camp."

- (Define outdoor adventure activities):

○ "By outdoor adventure activities, I mean anything from a hike to kayaking to rock climbing and whitewater rafting."

- "If you have any questions during the interview, please do not hesitate to stop me and ask. Thank you again for participating! Are you ready to start?"

\section{Questions}

Pt I: Main Questions 
1. At any point during the camp, did you feel that there was a time you overcame an obstacle through a lot of effort?

2. Before this camp, did you think of yourself as someone who is good at adventuring outdoors? Have those feelings changed after participating in this camp? If so, how?

a. What does it mean to you to be good at outdoor adventure activities?

3. How would you say that other people who know you, like your friends, teachers, and parents describe your interest and skill in outdoor adventure activities?

a. After participating in the camp, are those feelings changed? If so, how?

4. Prior to this camp, how did you feel about doing outdoor adventure activities such as hiking, biking, climbing, or rafting? How do you feel about doing outdoor activities such as these after participating in the camp?

5. Have you ever wanted to quit doing outdoor adventure activities because of a specific experience? If so, what happened and how do you feel you handled the situation?

6. Some would say that a lot of the activities you participated in during this camp are dangerous and risky. Do you feel that you can handle pressure well when participating in these types of outdoor adventure activities? What do you do to help cope with any pressure?

Pt II: Questions From Surveys

- Three or four question responses will be selected from the specific camper's survey.

- General question framing:

- In your survey, for the question "Overall, when I do outdoor recreation activities such as hiking, biking, rock climbing, and whitewater rafting, I feel confident, you wrote that you strongly disagree. Could you please elaborate on why you feel that way?" (let them answer)

- "Have your feelings about this camp? Why or why not?" changed at all now that you have participated in

Camper Demographics *Filled Out After the Interview by Researcher

Gender:

Race:

Age:

Grade:

State:

Relevant Registration Information: 


\section{Appendix B: Coding Table}

Table 5: Self-Efficacy Parent and Child Codes with Definitions

\begin{tabular}{|c|c|c|}
\hline Parent Codes with Definitions & Child Codes & Child Code Definitions \\
\hline \multirow{5}{*}{$\begin{array}{l}\text { Mastery/Non-Mastery Experience: } \\
\text { Attempts to overcome obstacles through } \\
\text { perseverant effort followed by successes } \\
\text { or failures. }\end{array}$} & $\begin{array}{l}\text { Sense of } \\
\text { Accomplishment }\end{array}$ & $\begin{array}{l}\text { Feeling(s of) achievement after having } \\
\text { participated in an activity or having new } \\
\text { thoughts about self }\end{array}$ \\
\hline & Sense of Failure & $\begin{array}{l}\text { Feeling that one missed to meet } \\
\text { expectations or accomplish certain tasks. } \\
\text { Expression of a lack of success, often } \\
\text { accompanied with negative feelings }\end{array}$ \\
\hline & Perseverance & $\begin{array}{l}\text { Overcoming or attempting to overcome an } \\
\text { obstacle(s) through continued effort or } \\
\text { through "stepping out of one's comfort } \\
\text { zone." }\end{array}$ \\
\hline & Avoidance & $\begin{array}{l}\text { Attempting to refrain from participating in } \\
\text { certain activities or tasks. Sometimes due to } \\
\text { fears of leaving "comfort zone." }\end{array}$ \\
\hline & Quitting & Completely stopping a task \\
\hline
\end{tabular}

Enjoyment: Whether someone does or does not enjoy something

OR Interest: Whether or not a participant is interested in OR activities or makes any mention of their interest in $\mathrm{OR}$ in general

Perceived Challenge: Whether or not one feels personally stimulated by a task or problem. How one feels about a task that may need great mental or physical effort to be done successfully.

Social Influence: Taking a specific action based on or having specific thoughts and feelings about $S$-E because of social standards and/or direct and indirect influence of peers.

\section{Motivation to Participate (in OR}

activities): Extent to which one desires to take part in an activity and why 
Physiological \& Emotional State: Mood (e.g. happy, sad, or excited). Thoughts about physical functioning of body (e.g. feeling tired or fatigued.).

Vicarious Experience: Seeing people similar to oneself succeed by sustained effort thus raising observers' beliefs that they too possess the capabilities to succeed in a similar situation.

Perceived Coping Abilities/Skills: How one feels about their capabilities in dealing with high pressure or stressful situations. Expression of the belief that they do or do not have the skills or expression of the specific skills they feel they have that can help them accomplish tasks in these high pressure situations.

Expectations: How one thinks that a certain event will go or how they believe they will react in a certain situation.

Exercise Self-Influence: The action or perceived ability to enact an action.

Previous Experience: Previous experiences one has (or the lack thereof) that may lead to higher (or lower) selfefficacy related to those experiences.

Perceived Safety/Risk: Extent to which someone feels they are exposed to danger or extent to which they feel the opposite.

Perceived OR Knowledge/Skills:

Perceived levels of OR-related

knowledge and/or skills

Perceived Mental State: One's feelings Calmness

about one's state of mind or mental condition at any given time.

Confidence: Expression of a feelings about certainty of abilities or self-reliance
Perceived Control

Over Mental State

Increase in Self-

Reported Confidence

Decrease in SelfReported Confidence
Self-reporting of growth in levels of confidence or feelings related to confidence after participating in the intervention.

Self-reporting of reduction in levels of confidence or feelings related to confidence after participating in the intervention. 


\section{Appendix C: Timeline}

This thesis proposal was submitted to committee members on September 19th, 2019.

Upon committee and Institutional Review Board approval, Appalachian GeoSTEM camp participants were contacted for interviews on June 23rd, 2019. Interviews took place near the conclusion of the camp session on June 29th, 2019. Data analysis began July, 2019 and was completed August, 2020. The final writing and revisions took place from May, 2020 to October, 2020. The defense for this thesis research project will take place on November $2 \mathrm{nd}, 2020$ via the video presentation software platform, Zoom. 


\section{Appendix D: Programmatic Overview of 2019 Appalachian GeoSTEM Camp}

\section{Appalachian GeoSTEM Camp Programmatic Overview}

\section{Sunday, June 23rd - Sunday, June 30th, 2019}

\section{Robert Burns}

Project Director, West Virginia University, Division of Forestry and Natural Resources, Director

John Brock

Project Director, United States Geological Survey, National Cooperative Geologic Mapping Program, Program Coordinator

Mike Marketti

United States Geological Survey, National Cooperative Geologic Mapping Program, Program Analyst

\section{C.J. Belknap}

Camp Course Director, West Virginia University, Adventure West Virginia Assistant Director

Emily Bunse

Camp Program Manager, Illinois State Geological Survey, Map Standards Coordinator

Lauren Janowicz

Camp Director, West Virginia University, Division of Forestry and Natural Resources Graduate Student

Mitch Blake

Director and State Geologist, West Virginia Geological and Economic Survey

\section{Campers}

- 20 camper max

- Ages 14 - 17 (entering 10-12th grade Fall 2019)

Locations

- WVU Evansdale Campus

○ Towers 
- Student Recreation Center

- Campus Tour

- WVU Outdoor Education Center \& Research Forest

- Coopers Rock State Forest

- Canaan Valley, WV

- Blackwater Falls, WV

- Thomas \& Davis, WV

- Seneca Rocks, WV

- Cheat Canyon, WV

- West Virginia Botanic Garden

- Laurel Caverns, PA

Partnerships

- United States Geological Survey (USGS)

- West Virginia University's Division of Forestry and Natural Resources (WVU DFNR)

- Adventure West Virginia (AWV)

- West Virginia Geological and Economic Survey (WVGES)

- Friends of Deckers Creek (FODC)

- West Virginia University's Natural Resource Analysis Center (NRAC)

- American Geosciences Institute (AGI)

- Pennsylvania Geological Survey (PA Department of Conservation \& Natural Resources)

Scholarships \& Subsidies

- Provided by the WVGES $(\$ 2,000.00)$

$\circ$ Two full scholarships

○ Four partial scholarships for up to $\$ 200.00$ each

- Provided by The Division of Forestry and Natural Resources $(\$ 2,000.00)$

- Price reduction for WV and non-WV campers

Main Activities

- Whitewater Rafting in Cheat Canyon

- Caving in Laurel Caverns

- Biking the Deckers Creek portion of the Rail Trail

- Zip-Lining at the WVU Research Forest

- Challenge Course at the WVU Research Forest

- Exploring Seneca Rocks

- Hiking at Coopers Rock State Forest

- Rock Climbing at Coopers Rock State Forest

- Acid Mine Drainage Site Stream Assessment at the WV Botanical Gardens and Friends of Deckers Creek's KCS1 Treatment Site

- Activity Day at the West Virginia Geological and Economic Survey

Evening Activities

- Outdoor and indoor activities at the WVU Student Recreation Center 
- Basketball

- Ping pong

- Can jam

- Bag toss

- Angle ball

○ Get-to-know-you games

- Owl Night Hike at the WVU Outdoor Education Center

- Mothing at the WVU Outdoor Education Center

- S'mores by the campfire at the WVU Outdoor Education Center

- Giant Swing at the WVU Outdoor Education Center

Lesson Modules

- Basic Mapping Concepts

- Basic Geologic Concepts

- Historical Geology of the Appalachian Mountain Region

- Geologic Mapping

- Environmental Science with an Emphasis on Hydrology

Technology

- 3D Point Mapping

- Structure-from-Motion

- Drones

- Route Mapping Software

- Analysis Software

- Mobile Apps:

$\circ$ iNaturalist

- StraboSpot

\section{Appalachian GeoSTEM Camp Teaching Philosophy Overview}

\section{Theoretical Framework}

- Experiential Learning Theory framework from Dewey and Kolb, and Stanchfield.

$\circ$ Experiential Learning is learning through doing and reflecting.

- Campers first grasp experience then transform or synthesize it.

- Experiential approach is based on idea that optimal change and growth take place when people are actively involved in their learning rather than simply receiving info.

- Link content to practical, social experience to make as relevant and meaningful as possible. 
- Not all of the info will get through to the campers so if we make it relevant and interesting to them, they're more likely to pursue geology \& natl. resources in the future

- Importance of down time - campers need time to digest information in order to reflect on their day and so that they have time to decompress after long days. Lessons are more effective when there is plenty of non-learning down time.

- Designing a Lesson for Active Learning

$\circ$ Lecture less than 30-45 minutes

- Learning on the go and hands-on learning are ideal

- Fewer slides, more demonstration \& hands-on activity

- Incorporate active use of technology as much as possible

- Creative, group activities

\section{Instruction \& Lessons}

- Learning Goals

$\circ$ 1) Introduction to Geology

- Basic ideas and mapping principles

$\circ$ 2) Use of Technology

- Collect data

- Exposure to and hands-on experience with current geoscience technology that is actually being used in the field today

$\circ \quad 3)$ Facilitate Collaborative Learning and Teamwork Outside of School Environment

- Encourage this among participants throughout camp

- 4) Relevance to Them

- Extremely important because relevance impacts their motivation to pursue geology and natural resources studies and interests in the future.

- Important to always consider how we can make the subject matter relevant and meaningful to the campers

- They can see how the information could apply to geoscience careers

- Generate interest by showing that this stuff is cool!

- Modules/Learning Objectives

- Modules are non-linear. Lessons often touch on multiple modules at one time.

- 1) Basic Mapping Concepts

- 2) Basic Geologic Concepts

- 3) Historical Geology of the Appalachian Mountain Region

- 4) Geologic Mapping

- 5) Environmental Science with an Emphasis on Hydrology

- Utilized Adventure West Virginia’s Science Behind The Sport programming

\section{(https://sciencebehindthesport.wvu.edu/ )}

Although this camp is unique, it was created through a blending of best practices in adventure recreation, informal learning, outdoor education, experiential learning, environmental 
education, and traditional summer camp. Using these aspects of best practices in well-researched fields utilized by camp managers, the researcher was able to link self-efficacy impacts understood in current literature to the unique program in the current study.

\section{References}

adVENTURE. (n.d.). Retrieved October 26, 2020, from https://adventure.ogsd.net/ American Camp Association. (2005). Youth development outcomes of the camp experience. https://www.acacamps.org/sites/default/files/resource_library/report-directions-youthdevelopment-outcomes.pdf

Artino, A. R. (2012). Academic self-efficacy: from educational theory to instructional practice. Perspectives on Medical Education, (1), 76-85. https://doi.org/10.1007/s40037-012-0012-5

Ary, D. J., Cheser, L., Razavieh, A., \& Sorensen, C. (2009). Introduction to research in education. (8th ed.). Wadsworth Publishing.

Bandura, A. (1977). Self-efficacy: Toward a unifying theory of behavioral change. Psychological Review, 84(2), 191-215. https://doi.org/10.1037/0033-295X.84.2.191

Bandura, A. (1994). Encyclopedia of mental health (Vol. 4). Academic Press.

Bandura, A. (2005). Guide for constructing self-efficacy scales. In Self-Efficacy Beliefs of Adolescents (pp. 307-337). Information Age Publishing.

Bandura, A., Barbaranelli, C., Caprara, G. V., \& Pastorelli, C. (2001). Self-efficacy beliefs as shapers of children's aspirations and career trajectories. Child Development, 72(1), 187206.

Banfield, J., \& Wilkerson, B. (2014). Increasing student intrinsic motivation and self-efficacy 
through gamification pedagogy. Contemporary Issues in Education Research, 7(4), 291298.

Banks, J. A., Au, K. H., Arnetha, Ball, F., Bell, P., Gordon, E. W., Gutiérrez, K. D., Brice Heath, S., Lee, C. D., Lee, Y., Mahiri, J., Na’ilah, Nasir, S., Valdés, G., \& Zhou, M. (2007). Learning in and out of school in diverse environments. Center for Multicultural Education, University of Washington, Seattle. http://depts.washington.edu/centerme/home.htm

Bell, J., Falk, J., Hughes, R., Hunt, G., Parrish, J., \& Sacco, K. (2016). Informal STEM education: Resources for outreach, engagement and broader impacts. The center for advancement of informal science education (CAISE).

Bell, P., Lewenstein, B., Shouse, A. W., \& Feder, M. (2009). Learning science in informal environments: People, places, and pursuits. National Academies Press.

Berliner, D. (2011). Rational responses to high stakes testing: The case of curriculum narrowing and the harm that follows. Cambridge Journal of Education, 41(3), 287-302. https://doi.org/10.1080/0305764X.2011.607151

Census bureau reports nearly 77 million students enrolled in U.S. schools. (2019, December 3). United States Census Bureau. Retrieved August 11, 2020, from, https://www.census.gov/newsroom/press-releases/2019/school-enrollment.html

Cheryan, S., Ziegler, S. A., Plaut, V. C., \& Metzoff, A. N. (2014). Designing classrooms to maximize student achievement. Education, 1(1), 4-12. https://doi.org/10.1177/2372732214548677

Creswell, J. W., \& Creswell, J. W. (2007). Qualitative inquiry \& research design: Choosing among five approaches. Sage Publications. 
Curtis, A. C. (2015). Defining adolescence. Journal of Adolescent and Family Health, 7(2). https://scholar.utc.edu/jafhAvailableat:https://scholar.utc.edu/jafh/vol7/iss2/2

Denson, C., Austin, C., Hailey, C., \& Householder, D. (2015). Benefits of informal learning environments: A focused examination of STEM-based program environments. Journal of STEM Education, 16(1).

DeWitt, J., \& Storksdieck, M. (2008). A short review of school field trips: Key findings from the past and implications for the future. Visitor Studies, 11(2), 181-197. https://doi.org/10.1080/10645570802355562

Michigan Division of Natural Resources. (n.d.). DNR Outdoor Adventure Center. https://www.michigan.gov/oac/

Duerden, M. D., Widmer, M. A., Taniguchi, S. T., \& McCoy, J. K. (2009). Adventures in identity development: The impact of adventure recreation on adolescent identity development. Identity, 9(4), 341-359. https://doi.org/10.1080/15283480903422806

Esters, L. T., \& Retallick, M. S. (2013). Effect of an experiential and work-based learning program on vocational identity, career decision self-efficacy, and career maturity. Career and Technical Education Research, 38(1), 69-83. https://doi.org/10.5328/cter38.1.69

Fägerstam, E. (2014). High school teachers' experience of the educational potential of outdoor teaching and learning. Journal of Adventure Education and Outdoor Learning, 14(1), 5681. https://doi.org/10.1080/14729679.2013.769887

Farmington Hills Nature Center. (n.d.). Retrieved October 22, 2020, from https://fhgov.com/Activities/Parks-Facilities/Nature-Center.aspx

Fields, D. A. (2009). What do students gain from a week at science camp? Youth perceptions 
and the design of an immersive, research-oriented astronomy camp. International Journal of Science Education, 31(2), 151-171. https://doi.org/10.1080/09500690701648291

Finn, K. E., Yan, Z., \& McInnis, K. J. (2018). Promoting physical activity and science learning in an outdoor education program. Journal of Physical Education, Recreation and Dance. https://doi.org/10.1080/07303084.2017.1390506

Fu, A. C., Peterson, L., Kannan, A., Shavelson, R. J., \& Kurpius, A. (2015). A framework for summative evaluation in informal science education. Visitor Studies, 18(1), 17-38. https://doi.org/10.1080/10645578.2015.1016363

Garst, B., Scheider, I., \& Baker, D. (2001). Outdoor adventure program participation impacts on adolescent self perception. The Journal of Experiential Education, 24(1), 41-49.

Garst, B., \& Whittington, A. (2020). Defining moments of summer camp experiences: An exploratory study with youth in early adolescence. Journal of Outdoor Recreation, Education, and Leadership, 12(3). https://doi.org/10.18666/JOREL-2020-V12-I3-10109

Gerber, B. L., Cavallo, A. M. L., \& Marek, E. A. (2001). Relationships among informal learning environments, teaching procedures and scientific reasoning ability. International Journal of Science Education, 23(5), 535-549. https://doi.org/10.1080/095006901750162892

Heinlein, A. G. (2017). Experiential learning in the middle school living environment experiential learning in the middle school living environment classroom. (Publication No. 863). [Master's thesis, SUNY Brockport, Master of Science in Education.] Digital Commons@Brockport.

Holmbeck, G. N. (2002). A developmental perspective on adolescent health and illness: an introduction to the special issues. Journal of Pediatric Psychology, 27(5), 409-416. https://doi.org/10.1093/jpepsy/27.5.409 
Houge Mackenzie, S., \& Hodge, K. (2019). Adventure recreation and subjective well-being: A conceptual framework. Leisure Studies, 39(1), 26-40. https://doi.org/10.1080/02614367.2019.1577478

Hsieh, H. F., \& Shannon, S. E. (2005). Three approaches to qualitative content analysis. Qualitative Health Research, 15(9), 1277-1288. https://doi.org/10.1177/1049732305276687

Ilker Etikan, Abubakar Musa, S., \& Sunusi Alkassim, R. (2016). Comparison of convenience sampling and purposive sampling. American Journal of Theoretical and Applied Statistics, 5(1), 1. https://doi.org/10.11648/j.ajtas.20160501.11

James, J. K., \& Williams, T. (2017). School-based experiential outdoor education: A neglected necessity. Journal of Experiential Education, 40(1), 58-71. https://doi.org/10.1177/1053825916676190

Jones, J. J., \& Hinton, J. L. (2007). Study of self-efficacy in a freshman wilderness experience program: Measuring general versus specific gains. Journal of Experiential Education, 29(3), 382-385.

Kliebard, H. M. (2004). The struggle for the American curriculum, 1893 - 1958 (Third). RoutledgeFalmer.

Kolb, D. A. (1984). Experiential learning: Experience as the source of learning and development executive skills of family medicine faculty view project learning sustainability view project. Prentice-Hall, Inc.

Lane, H. C., Cahill, C., Foutz, S., Auerbach, D., Noren, D., Lussenhop, C., \& Swartout, W. 
(2013). In Lane, H. C., Yacef, K., Mostow, J., Pavlik, P. (Eds.), The effects of a pedagogical agent for informal science education on learner behaviors and self-efficacy. Springer, Berlin, Heidelberg. https://doi.org/10.1007/978-3-642-39112-5_32

Locklear, E. (2013). 4-H Science Initiative from Inception to Impact.

Mackenzie, S. H., \& Eitel, K. (2017). Engaging youth in physical activity and STEM subjects through outdoor adventure education. Journal of Outdoor and Environmental Education, 20(2), 32-44. https://www.researchgate.net/publication/320553139

Mackenzie, S. H., Son, J. S., \& Eitel, K. (2018). Using outdoor adventure to enhance intrinsic motivation and engagement in science and physical activity: An exploratory study. Journal of Outdoor Recreation and Tourism. 21, 76-86. https://doi.org/10.1016/j.jort.2018.01.008

Marin, L. M., \& Halpern, D. F. (2011). Pedagogy for developing critical thinking in adolescents: Explicit instruction produces greatest gains. Thinking Skills and Creativity, 6(1), 1-13. https://doi.org/10.1016/j.tsc.2010.08.002

Martin, K. (2018). Summer camp youth leadership development: an investigation of adolescents' perceptions of best practices. Journal of Youth Development, 13(1-2), 161-182. https://doi.org/10.5195/jyd.2018.536

Martin, L. M. W. (2004). An emerging research framework for studying informal learning and schools. Science Education, 88, 71-82. https://doi.org/10.1002/sce.20020

Mayring, P. (2000). Qualitative content analysis. In Flick, U., von Kardorff, E., \& Steinke, I. (Eds.), A Companion to Qualitative Research. SAGE Publications.

McGeown, S. P., Putwain, D., Geijer-Simpson, E., Boffey, E., Markham, J., \& Vince, A. (2014). 
Predictors of adolescents' academic motivation: Personality, self-efficacy and adolescents' characteristics. Learning and Individual Differences, 32, 278-286.

Mittelstaedt, R. D., \& Jones, J. J. (2009). Outdoor recreation self-efficacy: scale development and reliability. Journal of Outdoor Recreation, Education, and Leadership. 1(1), 97-120. https://doi.org/10.7768/1948-5123.1006

Mohr-Schroeder, M., Jackson, C., Miller, M., Walcott, B., Little, D. L., Speler, L., Schooler, W., \& Schroeder, D. C. (2014). Developing middle school students' interests in stem via summer learning experiences: See blue stem camp. School Science and Mathematics, 114(6). https://doi.org/10.1111/ssm.12079

Mutz, M., \& Müller, J. (2016). Mental health benefits of outdoor adventures: Results from two pilot studies. Journal of Adolescence, 49, 105-114. https://doi.org/10.1016/j.adolescence.2016.03.009

Neuendorf, K. A. (2017). The content analysis guidebook (2nd edition). SAGE Publications.

Ngaka, W., Openjuru, G., \& Mazur, R. E. (2012). Exploring formal and non-formal education practices for integrated and diverse learning environments in Uganda. The International Journal of Diversity in Organizations, Communities, and Nations, 11(2).

Passarelli, A., Hall, E., \& Anderson, M. (2010). A strengths-based approach to outdoor and adventure education: Possibilities for personal growth. Journal of Experiential Education, 33(2), 120-135. https://doi.org/10.5193/jee33.2.120

Paxton, T., \& McAvoy, L. (2000). Social psychological benefits of a wilderness adventure program (Vol. 3).

Popovic, G., \& Lederman, J. S. (2015). Implications of informal education experiences for 
mathematics teachers' ability to make connections beyond the formal classroom. School Science and Mathematics, 115(3), 129-140.

Richmond, D., Sibthorp, J., Gookin, J., Annarella, S., \& Ferri, S. (2018). Complementing classroom learning through outdoor adventure education: out-of-school-time experiences that make a difference. Journal of Adventure Education and Outdoor Learning, 18(1), 36-52. https://doi.org/10.1080/14729679.2017.1324313

Roberts, T., Jackson, C., Mohr-Schroeder, M. J., Bush, S. B., Maiorca, C., Cavalcanti, M., Craig Schroeder, D., Delaney, A., Putnam, L., \& Cremeans, C. (2018). Students’ perceptions of STEM learning after participating in a summer informal learning experience. International Journal of STEM Education, 5(1). https://doi.org/10.1186/s40594-0180133-4

Rogoff, B., Callanan, M., Gutiérrez, K. D., \& Erickson, F. (2016). The organization of informal learning. 40, 356-401. https://doi.org/10.3102/0091732X16680994

Saldaña, J. (2013). The coding manual for qualitative researchers (2nd ed.). SAGE Publications.

Sasson, I. (2014). The role of informal science centers in science education: Attitudes, skills, and self-efficacy. Journal of Technology and Science Education, 4(3). https://doi.org/10.3926/jotse.123

Schwartz, F., \& Belknap, C. J. (2017). Effects of a college outdoor orientation program on trait emotional intelligence. Journal of Outdoor Recreation, Education, and Leadership, 9(1), 69-82. https://doi.org/https://doi.org/10.18666-2017-V9-I1-7429

Science adventure school. (n.d.). West Virginia University. Retrieved October 26, 2020, from https://scienceadventureschool.wvu.edu/

Shellman, A., \& Ewert, A. (2010). A multi-method approach to understanding empowerment 
processes and outcomes of adventure education program experiences. Journal of Experiential Education, 32(3), 275-279.

Sleeter, C. E. (2015). Multicultural education vs. factory model schooling - In Baptiste, H. P., Ryan, A., Arajuo, B., \& Duhonsells, R. (Eds.), Multicultural education: A renewed paradigm of transformation and call to action. $(115$ - 136). San Francisco: Caddo Gap Press.

Smith-Palmer, T., Schnepf, S., Sherman, A., Sullenger, K. S., \& Macdonald, L. (2015). An exploration of summer science camps as an informal learning environment. In K. S. Sullenger \& R. S. Turner (Eds.), New Ground: Pushing the Boundaries of Studying Informal Learning in Science, Mathematics, and Technology (67-91). Sense Publishers.

South Dakota school of mines geology rocks! summer camp. (n.d.). Retrieved October 26, 2020, from https://www.sdsmt.edu/Academics/Events-and-Outreach/Summer-Camps/Camp--Geology-Rocks/

Stanchfield, J. (2016). Tips \& tools for the art of experiential group facilitation (2nd edition). Wood N Barnes Publishing.

Toomey Zimmerman, H., \& Bell, P. (2012). Everyday expertise: Learning within and across formal and informal settings. In Jonassen, D. \& Land, S. (Eds.), Theoretical Foundations of Learning Environments (224-241) Routledge.

UNESCO Institute for Statistics. (n.d.). Formal education. http://uis.unesco.org/node/334633 University of Huddersfield. (n.d.). Themes and codes. https://research.hud.ac.uk/researchsubjects/human-health/template-analysis/technique/themes-and-codes/ 
Utah Governor's Office of Economic Development. (2020). Utah governor's office of economic development annual report. https://business.utah.gov/wp-content/uploads/2020/10/2020GOED-Annual-Report.pdf

Watters, A. L., Stabulas-Savage, J., Toppin, J. D., Janal, M. N., \& Robbins, M. R. (2015). Incorporating experiential learning techniques to improve self-efficacy in clinical special care dentistry education. Journal of Dental Education, 79(9), 1016-1023. https://doi.org/10.1002/j.0022-0337.2015.79.9.tb05994.x

Widmer, M. A., Duerden, M. D., \& Taniguchi, S. T. (2014). Increasing and generalizing selfefficacy: The effects of adventure recreation on the academic efficacy of early adolescents. In Journal of Leisure Research Copyright (Vol. 46, Issue 2).

Wilson, C., Akiva, T., Sibthorp, J., \& Browne, L. P. (2019). Fostering distinct and transferable learning via summer camp. Children and Youth Services Review, 98, 269-277. https://doi.org/10.1016/j.childyouth.2019.01.017

Yilmaz, M., Ren, J., Ramirez, D., Custer, S., \& Coleman, J. (2010). An Improved K 12 Outreach Camp for Engineering Disciplines. 2010 Annual Conference \& Exposition Proceedings, 15.154.1-15.154.8. https://doi.org/10.18260/1-2--16516

Zimmerman, B. J., \& Cleary, T. J. (2006). Adolescents' development of personal agency: The role of self-efficacy beliefs and self-regulatory skill. In Pajares, F. \& Urdan, T. (Eds.), SelfEfficacy Beliefs of Adolescents (45-70). Information Age Publishing. 